\title{
Recent Progress in Enhancing Fungal Disease Resistance in Ornamental Plants
}

\author{
Manjulatha Mekapogu ${ }^{1}$, Jae-A Jung ${ }^{1, *}{ }^{\circledR}$, Oh-Keun Kwon ${ }^{1}$, Myung-Suk Ahn ${ }^{1}$, Hyun-Young Song ${ }^{1}$ \\ and Seonghoe Jang ${ }^{2, *}$ (D)
}

1 Floriculture Research Division, National Institute of Horticultural and Herbal Science, Rural Development Administration, Wanju 55365, Korea; manjubio7@gmail.com (M.M.); kok5510@korea.kr (O.-K.K.); ahnms@korea.kr (M.-S.A.); shy0817@korea.kr (H.-Y.S.)

2 World Vegetable Center Korea Office (WKO), Wanju 55365, Korea

* Correspondence: jabisung@korea.kr (J.-A.J.); seonghoe.jang@worldveg.org (S.J.)

check for updates

Citation: Mekapogu, M.; Jung, J.-A.; Kwon, O.-K.; Ahn, M.-S.; Song, H.-Y.; Jang, S. Recent Progress in Enhancing Fungal Disease Resistance in Ornamental Plants. Int. J. Mol. Sci. 2021, 22, 7956. https://doi.org/ 10.3390/ijms22157956

Academic Editor: Maria R. Ercolano

Received: 16 June 2021

Accepted: 23 July 2021

Published: 26 July 2021

Publisher's Note: MDPI stays neutral with regard to jurisdictional claims in published maps and institutional affiliations.

Copyright: (c) 2021 by the authors. Licensee MDPI, Basel, Switzerland. This article is an open access article distributed under the terms and conditions of the Creative Commons Attribution (CC BY) license (https:// creativecommons.org/licenses/by/ $4.0 /)$.

\begin{abstract}
Fungal diseases pose a major threat to ornamental plants, with an increasing percentage of pathogen-driven host losses. In ornamental plants, management of the majority of fungal diseases primarily depends upon chemical control methods that are often non-specific. Host basal resistance, which is deficient in many ornamental plants, plays a key role in combating diseases. Despite their economic importance, conventional and molecular breeding approaches in ornamental plants to facilitate disease resistance are lagging, and this is predominantly due to their complex genomes, limited availability of gene pools, and degree of heterozygosity. Although genetic engineering in ornamental plants offers feasible methods to overcome the intrinsic barriers of classical breeding, achievements have mainly been reported only in regard to the modification of floral attributes in ornamentals. The unavailability of transformation protocols and candidate gene resources for several ornamental crops presents an obstacle for tackling the functional studies on disease resistance. Recently, multiomics technologies, in combination with genome editing tools, have provided shortcuts to examine the molecular and genetic regulatory mechanisms underlying fungal disease resistance, ultimately leading to the subsequent advances in the development of novel cultivars with desired fungal disease-resistant traits, in ornamental crops. Although fungal diseases constitute the majority of ornamental plant diseases, a comprehensive overview of this highly important fungal disease resistance seems to be insufficient in the field of ornamental horticulture. Hence, in this review, we highlight the representative mechanisms of the fungal infection-related resistance to pathogens in plants, with a focus on ornamental crops. Recent progress in molecular breeding, genetic engineering strategies, and RNAi technologies, such as HIGS and SIGS for the enhancement of fungal disease resistance in various important ornamental crops, is also described.
\end{abstract}

Keywords: fungal diseases; genetic engineering; HIGS (host-induced gene silencing); SIGS (sprayinduced gene silencing); ornamental plants; resistance mechanisms; breeding technology; Botrytis cinerea; Fusarium oxysporum; Alternaria sp.

\section{Introduction}

Ornamental plants possess natural beauty and are distinctive due to their exquisite blooms. The alluring colors and shapes of their flowers, leaves, and fruits of these plants are a source of major attraction. Ornamental crops are grown for various decorative purposes as potted plants, woody ornamentals, cut flowers or cut foliage, bulbs, and corms [1]. The floriculture sector is flourishing globally and is experiencing increased demand. Floriculture has significantly impacted the horticultural industry by facilitating a substantial turnover with regard to all aspects of floriculture, of which roughly one third of the global value of the ornamental market is made up of cut flowers [2]. The turnover of popular ornamental plants in the world's largest flower auction, the Royal FloraHolland auction is detailed in Table 1 [3] (FloraHolland Key figures, 2019). As this represents a 
dynamic sector, introducing novelties into the market is a mandate for withstanding global competitiveness.

Table 1. Turnover of the top 10 ornamental plants in the Royal FloraHolland auction in 2019.

\begin{tabular}{ccc}
\hline S.No & Ornamental Plants Sold & Turnover (Million Euros) \\
\hline 1 & Rose & 696 \\
2 & Chrysanthemum & 328 \\
3 & Phalaenopsis & 460 \\
4 & Tulip & 285 \\
5 & Gerbera & 148 \\
6 & Lily & 144 \\
7 & Kalanchoe & 65 \\
8 & Anthurium & 60 \\
9 & Potted rose & 57 \\
10 & Lavender & 20 \\
\hline
\end{tabular}

Plant pathogens cause severe losses in the production and/or quality of various ornamental crops and this is of great economic significance. Their effects range from mild symptoms to catastrophes, where larger areas of planted crops are seriously damaged [4]. Ornamental plants in general are infected by a myriad of microbial organisms, including bacteria, fungi, and viruses, that severely affect the growth and morphology of these plants and thereby influence their commercial value. The visual quality of ornamental plants is critical, particularly for cut flowers and potted plants. Visual disease symptoms and the impact on growth caused by pathogens both heavily affect the quality and the market value of the flowers. Hence, ensuring quality traits in these plants is essential as they face increasing demand for industrial purposes [5].

Among the diseases caused by fungi, bacteria, viruses, and viroids, approximately $70 \%$ of those in plants are caused by fungi. In many cases, fungal diseases cause a significant reduction in crop quality and yield that can represent up to $30-40 \%$ of the total potential yield [6]. Fungi are estimated to be the biggest threat and the major cause underlying pathogen-driven host losses, declining the visual quality and lowering of market prices of ornamental flowers [7]. The majority of plant fungi are strictly saprophytic and derive their nutrition from dead organic matter, while the remaining are pathogenic biotrophic and necrotropic fungi that grow on living plants and cause diseases [8]. Plant fungal pathogens can be largely classified into the phyla Ascomycota and Basidiomycota. Ascomycetes are represented by various classes of pathogens such as Sordariomycetes (Magnaporthe spp.), Dothideomycetes (Cladosporium spp.), and Leotiomycetes (Botrytis spp.), while Basidiomycetes includes two larger groups of plant pathogens such as the rusts (Pucciniomycetes) and the smuts (Ustilaginomycetes). Based on the nature of their interaction with plants, these pathogenic fungi are grouped into biotrophs that form an intimate interaction with the host plant and utilize its living tissues and the necrotrophs that kill the plant tissues by causing cellular necrosis that eventually leads to plant death [9]. Obligate biotrophic fungi cannot grow without a living host and cause various diseases in ornamental plants such as leaf spots, blights, rusts, smuts, powdery mildew disease, and downy mildew disease.

Frequently, fungal diseases are managed by the application of chemical fungicides that are effective only for a few diseases and are sometimes non-specific. Moreover, excessive use of chemicals results in pathogen resistance against these chemicals and is highly undesirable due to health and environmental safety concerns [10]. An alternative method to chemical control is the biological control of pathogens, and this can be achieved through an integrated approach for disease management [1]. However, the scope of disease control provided by biocontrol methods is very limited. The formulations of beneficial fungi or bacteria that suppress plant pathogen growth usually provide some degree of control and can only be used as a component of the IPM strategy [11]. Hence, the ultimate goal is to generate plants that possess increased resistance to diseases. Effective control of diseases can be achieved by host basal resistance, 
as this can reduce the requirements of pesticide application. However, not all ornamental plants possess natural disease resistance; therefore, disease management relies on the use of disease-resistant varieties. Hence, it is important to elucidate pathogenicity and host-pathogen interactions to develop novel strategies for improving disease resistance in plants [12]. The development of disease-resistant varieties is possible via traditional breeding approaches or genetic engineering by introducing resistance mechanisms derived from other plant species or pathogens [13]. The introduction of natural resistance by traditional breeding approaches includes non-transgenic breeding programs, such as DNA-based marker-assisted selection that may require several cycles of breeding to combine the disease-resistant trait and desirable ornamental characteristics into a single plant genotype. In contrast, the transgenic approach uses tightly regulated transgenes to introduce specific or broad-spectrum disease resistance into genotypes with elite ornamental qualities [14]. Breeding efforts to achieve disease resistance in ornamental plants are comparatively limited, as the disease-resistance trait is typically taken into consideration only during the later stages of the breeding line selection process of cultivar development [15]. Genetic mapping of disease resistance is relatively scarce due to the large and complex genomes and the nature of the polyploidy present in most ornamental plants, as these characteristics require a greater number of resources and more time to map the resistance mechanisms [16]. Nevertheless, recent advances in genomesequencing technologies, phenotyping, marker development, and genotyping have provided a promising base for further breeding development for disease resistance in ornamental plants. Alternatively, genetic engineering technology provides a potential platform for the improvement of resistance to a myriad of biotic and abiotic stresses in ornamental plants, thus improving plant quality. Tolerance to several fungal diseases has been achieved by transferring various genes such as glucanase, chitinase, defensin, osmotin, and pathogenesis-related (PR) genes into ornamental plants [17]. RNA interference (RNAi) strategies have also demonstrated the potential to protect plants against pathogens, and one of these strategies is host-induced gene silencing (HIGS), mediated by RNAi signals generated in planta [18]. In addition to HIGS, a novel strategy designated as 'spray-induced gene silencing' (SIGS) has been demonstrated to protect plants from fungal pathogens through the direct spraying of dsRNA-targeting pathogen genes in plant tissues, thus displaying the potential to be used as an alternative to conventional fungicides [19]. Furthermore, advances in genome editing technology and its applications have offered greater possibilities with regard to precise manipulation of the genome sequences at genes of interest, and these techniques are currently being used to improve disease resistance in plants [20]. Research advances, such as biotechnological advancements used for improving resistance against fungal diseases in some economically important ornamentals such as the rose, chrysanthemum, gerbera, lily, carnation, and petunia, are discussed in the current review.

\section{General Mechanisms of Fungal Pathogen Infection and Plant Resistance}

Various fungi can infect different parts of plants, including the aerial and the underground parts. Typically, many fungal pathogens exhibit organ specificity and do not attack all parts of the host plant. The general establishment of fungal infection and pathogenicity involves the following steps: (a) adhesion to the plant surface, (b) germination on the plant surface and formation of infection structures, (c) penetration of the host, and (d) colonization of the host tissue [21]. For the initial step of fungal attachment to the plant surface, fungi utilize different mechanisms for different organs and roots due to variations in the surface hydrophobicities of these structures. Secretion of extracellular enzymes from spores is required for adhesion to the plant surface. The aerial parts of the plant are protected with a cuticle that includes pectin, cutin, and wax layers, and the cutin-degrading enzyme cutinase is associated with fungal pathogenicity [22]. Adhesion of spores to host surfaces requires spore-tip mucilage that is released upon the hydration of conidia from the periplasmic compartment of the conidial apex, ultimately resulting in spore-wall rupture [23]. The second step of fungal pathogenicity is spore germination and filamentous germ tube formation, a process that involves complete cell reprogramming and requires 
specific regulatory networks. After the spore germinates, it produces a germ tube that differentiates into an appressorium. Previous reports have suggested that a G-protein-coupled receptor (Pth11) and cognate G- $\alpha$ - and G- $\beta \gamma$-subunit proteins are required for appressorium development on hydrophobic surfaces $[24,25]$. The appressorium in turn produces an infection peg and applies a turgor-driven mechanical pressure of approximately $8.0 \mathrm{MPa}$ onto the peg that then pierces the cuticle and grows into the plant's underlying epidermal cell [26]. The infectious hypha then branches into the secondary hyphae that spread interand intra-cellularly within the host tissue [21]. The general mechanism of fungal infection is presented in Figure 1.

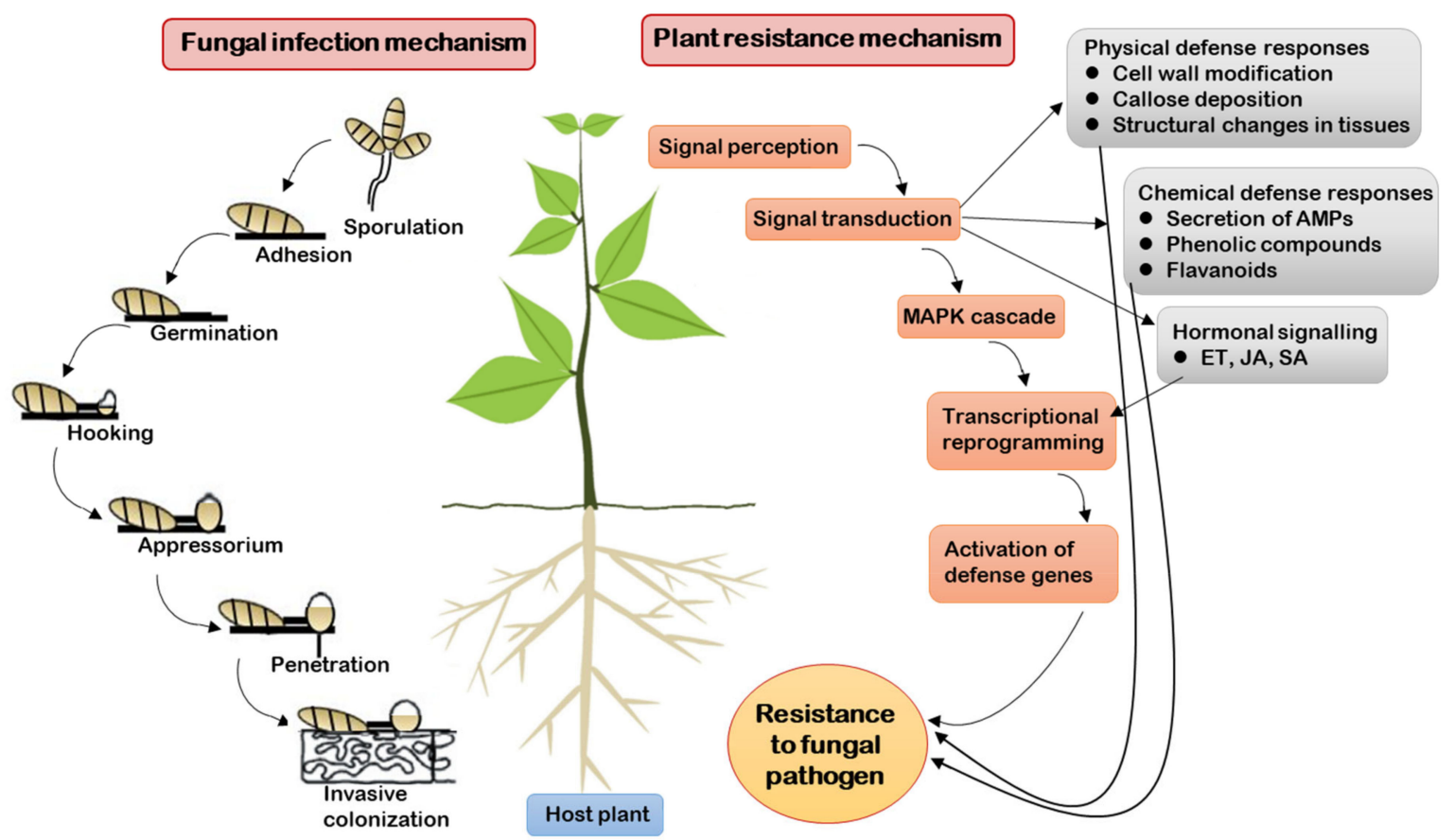

Figure 1. Schematic representation of the various steps involved in the fungal infection process and the general mechanism of the defense response of the host plant machinery to combat the fungal pathogen and to provide resistance.

Plants are equipped with multilayered defense mechanisms to fight pathogenic microorganisms [27]. They depend upon the ability of their immune system to identify the pathogen, activate signal transduction, and perform defense responses through pathways that involve numerous genes [28]. Plants have evolved to obtain resistance against pathogens by preventing pathogens from gaining access to the cell through the use of physiological barriers and surface-recognition features [29,30]. After sensing the pathogen, the plant's trans-membrane receptors and intracellular receptors activate defense systems, either by physically interacting with pathogen-derived immunogens or by examining the host-target modifications induced by the pathogen [31,32]. Furthermore, plant-derived antimicrobial peptides, that are produced in response to infection, function to suppress pathogenicity by facilitating direct detoxification or by inhibiting the activity of pathogenic factors [33,34]. Pattern-recognition receptors (PRRs) play a key role in plant defense mechanisms [35]. PRRs recognize pathogen-associated molecular patterns (PAMPs) and eventually initiate PAMP-triggered immunity (PTI) that functions as a specific plant defense response against pathogens [28,36]. However, plants often experience effector-triggered susceptibility (ETS) where several pathogens secrete effectors to defend the plant PTI and suppress it by activating susceptibility (S) proteins, ultimately progressing the infection [35]. Subsequently, the second line of defense in plants is activated to respond to these effectors by recruiting resistance $(R)$ genes. Signals from effector molecules activate $R$ genes, thus leading to effector-triggered immunity (ETI) [37]. Both PTI and ETI result in the induction of pathogenesis-related (PR) genes, and the activation of mitogen-activated protein kinase 
(MAPK) cascades that function as important signal transducers to channel information through protein phosphorylation/dephosphorylation processes [38]. Furthermore, MAPKs promote defense systems that threaten the survival of fungal cells by inducing downstream responses, including hypersensitive response (HR), cell-wall modification, callose deposition at the site of infection, and secretion of antimicrobial proteins (AMPs) such as chitinases, defensins, phytoalexins, and protease inhibitors [28,39]. In addition to these plant immune responses, the host plant may induce immune responses that are specific to the infecting fungal culture [40,41]. Plant hormones play a significant role in signal transduction during plant defense. The salicylic acid (SA) pathway is stimulated during the defense response against biotrophic and hemibiotrophic pathogens, while primary hormones such as jasmonate (JA) and ethylene (ET) are involved in the defense response against necrotrophic pathogens [42]. The general mechanism of plant resistance to fungal pathogens is presented in Figure 1.

\section{Molecular Breeding for Fungal Disease Resistance}

Despite the rapidly growing economic importance of ornamental crops, the breeding strategies used for developing new cultivars which possess disease resistance, lag behind those of other agricultural crops. Complex genomes, limited availability of gene pools, and a lack of genetic variability within these gene pools are major limitations in the use of conventional breeding to acquire disease resistance in ornamental plants. However, relentless efforts to map disease resistance traits and to facilitate the introgression of disease resistance genes into superior ornamental plants, have been put forth in combination with recent technological progress in genome sequencing, genotyping, and the development of markers. Among the molecular tools used for efficient breeding, marker-assisted breeding (MAB) approaches, which use trait-linked molecular markers identified from genetic, genomic, and molecular studies, have enabled the development of more effective selection strategies [43]. In particular, the MAB for disease-resistance traits, that generally require simultaneous combinations of multiple genes, has been deployed to enhance efficiency. Moreover, MAB may efficiently facilitate target-gene introgression from the wild species genomes against the genetic background of wild donors [44]. Ornamental crops possess the desired set of traits for floral characteristics such as floral color, shape, and size. Therefore, making ornamental plants resistant to diseases in addition to possessing these floral traits is required for hundreds of cultivars [45].

In the rose plant (Rosa hybrida), several markers, such as amplified fragment length polymorphisms (AFLPs), restriction fragment length polymorphisms (RFLPs), simple sequence repeats (SSRs), cleaved amplified polymorphic sequences (CAPS), sequence-characterized amplified regions (SCARs), and various other markers have been developed and subsequently utilized to create diploid and tetraploid maps of roses [46-48]. Loci for a number of diseaseresistant traits have been determined from those maps, and three $R d r$ genes have also been localized on the rose genome. Additionally, their quantitative inheritance pattern has been analyzed for black spots [49]. Linde et al. (2004) mapped a dominant-resistance gene (Rpp1) that exhibited race-specific resistance to powdery mildew in roses by utilizing newly developed SCAR markers [50]. Several quantitative trait loci (QTLs) specific for resistance to powdery mildew have also been reported in roses [51-53]. Four markers for two QTLs have been reported in Rosa roxburghii for powdery mildew resistance; three of these are associated with $R d r 1$, while the last is associated with $R d r 3$ [54,55]. Additionally, Terefe-Ayana et al. (2011) reported the molecular characterization of the dominant resistance gene $R d r 1$, against one isolate of the leaf spot pathogen Diplocarpon rosae in roses [56]. Recently, four MLO genes that serve as candidate genes for powdery mildew resistance have been mapped to three linkage groups in roses [57].

Although traditional breeding has led to the development of numerous chrysanthemum cultivars as one of the most popular ornamental plants, the application of molecular breeding for fungal disease resistance is still lagging compared to that of other crops, and this is primarily due to the complex genome allohexaploidy, heterozygosity, self-incompatibility, 
and the inbreeding depression of this plant [43]. Thus, approaches using genetic mapping, genome-wide association studies (GWAS), and molecular markers associated with traits in chrysanthemum have been limited [58]. An AFLP marker linked to white rust resistance was developed using bulk segregant analysis (BSA). This AFLP marker was further converted into an SCAR marker that was confirmed in the pseudo-F1 test cross [59]. Hence, this marker can be successfully used to screen white rust-resistant populations in chrysanthemum breeding programs. Genome sequence information for a diploid wild Chrysanthemum seticuspe will help to accelerate the molecular breeding of chrysanthemum for disease resistance [60].

The lily (Lillium) is the most economically important monocot bulbaceous flower. However, breeding for disease resistance in lilies is hindered due to their long juvenile phase that limits the selection process for the introgression of desired traits into a single cultivar. Significant QTL mapping for Fusarium resistance in lilies was conducted, and the results demonstrated the mapping of four QTLs to linkage groups 1, 5, 13, and 16 of the AFLP genetic map [61]. Among these four QTLs, the most tightly linked markers to the two significant QTLs for Fusarium resistance were converted into robust PCR-based markers that can be successfully used in molecular breeding in lilies [62]. Later, Shahin et al. (2011) remapped major genes for Fusarium disease resistance in lilies using three different molecular marker systems (AFLP, DArT, and NBS profiling), thus resulting in the identification of two additional QTLs for Fusarium resistance [63]. Recently, high-quality transcriptomic analyses of lilies and tulips have become available and these offer valuable information for use in the genomic studies of bulbous plants [64]. Tang et al. (2015) constructed a genetic linkage map for Fusarium resistance in tulips using a combined set of AFLP, NBS, and SSR markers, thus leading to the identification of six putative QTLs. Of these, three were well-matched to the phenotype and could be used for marker-assisted selection (MAS) in tulip breeding [65].

Gerbera hybrida is a commercially predominant and popular cut-flower crop that is also a highly heterozygous ornamental plant. To date, only a limited number of resistance gene analogs (RGAs) and SSR markers have been available for genetic studies in gerbera. However, reliable single-nucleotide polymorphism (SNP) markers have been identified from the transcriptomic analyses of four gerbera genotypes, and these can be further used in the mapping and genetic studies of gerbera. This study also predicted the candidate genes that were related to the biosynthetic pathways of ethylene and jasmonate and the signaling networks that are considered to play a role in plant resistance against Botryitis cinerea [66]. The SNP markers identified in the study were further used to construct the first genetic linkage map in gerbera, and a QTL map was developed for resistance to $B$. cinera. A total of 20 QTLs were identified, thus reflecting the complex mechanism of the defense response of this plant against $B$. cinera [67].

The carnation (Dianthus caryophyllus) is one of the major ornamental cut flowers worldwide. The carnation is diploid and its genome size is relatively small, compared to that of other ornamental crops. To contribute to molecular and genetic studies, transcriptome analysis was performed in the carnation and the resulting data revealed 17,362 potential SSRs and 14,291 unigenes [68]. Yagi et al. (2013) constructed a high-density genetic linkage map based on SSR markers using RNA-sequence analyses [69]. This genetic linkage map combined with SSR markers serves as a reference genetic linkage map for the members of Dianthus, including the carnation, and it can be further used for the mapping of QTLs that are associated with the disease-resistant traits in carnation-breeding programs to develop improved varieties. Recently, the whole-genome sequence of the carnation (Dianthus caryophyllus L. cv. Francesco) was determined, ultimately revealing various genes related to disease resistance, floral scent, color, and different metabolic pathways. Additionally, this information served as a resource for fundamental and applied research on carnations, particularly with regard to developing new carnation varieties through molecular breeding approaches [70]. 


\section{Genetic Engineering for Improved Fungal Disease Resistance in Ornamental Plants}

Although various fungal diseases are managed by fungicide application, fungicides are often non-specific and kill beneficial microbes along with pathogens. Moreover, most fungicides are hazardous chemicals to both human and environmental health. Additionally, excessive use of these chemicals can cause resistance to fungicides [71]. Hence, the development of fungal disease-resistant cultivars would provide a promising alternative method for efficient ornamental production with minimal losses by fungal pathogens. The development of fungal disease resistance through conventional breeding is hindered by several limitations such as deficiency of gene resources for many diseases, the transfer of undesirable traits along with resistant genes, and the rapid evolution of the ability of pathogens to overcome plant-resistance mechanisms [72]. Alternatively, genetic engineering possesses the potential to overcome the barriers in traditional breeding methods and to control the ability of the plant to identify and defend itself against fungal diseases. Advances in genetic engineering have enabled researchers to better understand the molecular mechanisms of plant defense responses, thus contributing to the development of novel strategies to combat the disease [6]. In contrast to conventional breeding, genetic engineering offers the possibility of increasing the disease resistance to several pathogens simultaneously, and the gene of interest can be introduced into the target plant even if the gene does not exist in the natural gene pool [2]. Advances in genetic engineering to achieve fungal disease resistance in various ornamental plants are discussed in this section.

\subsection{Rose}

Roses (Rosa hybrida) are cultivated throughout the world and are an economically important ornamental plant worldwide. Roses are most admired for their beauty and fragrance, and they exhibit alluring colors. Within the Rosa genus, there are more than 200 rose species and over 30,000 cultivars. They are used as cut flowers, pot plants, and garden plants [73]. Rose-petal essential oils consist of beneficial secondary metabolites that are used in the natural medicine, cosmetics, and perfume industries [74]. However, rose cultivation is severely impaired by major fungal diseases such as powdery mildew, black spots, botrytis blight, downy mildew, and rust that adversely affect yields and product quality [75]. Despite the economic importance of the rose as an ornamental crop, breeding progress for fungal resistance is lagging in roses due to insufficient information regarding disease-resistant traits. Moreover, a higher level of heterozygosity, sterility, and polyploidy are the major limitations of traditional breeding for fungal disease resistance in roses [76]. Hence, genetic engineering is a desirable approach to induce resistance against fungal diseases. Powdery mildew caused by the obligate ascomycete pathogen Podosphaera pannosa (Wallr.: Fr.) is one of the predominant fungal diseases of rose. It causes distortion and senescence of the leaves and shoots. Approximately $40 \%$ of the fungicide sprayed on cut and potted roses is used to control powdery mildew [77]. It is known that PR genes, including $\beta-1,3$-glucanase, chitinase, ribosome-inactivating protein (RIP), and cysteine-rich antimicrobial protein $(A M P)$, are triggered during fungal pathogen infections $[78,79]$. These antifungal proteins, including chitinases, glucanases, RIPs, plant defensins, and proteinase inhibitors, function by disrupting or suppressing the synthesis of the fungal cell wall. Some of these proteins interact with potential intracellular targets and the plasma membrane of fungi, thus leading to changes in membrane potential and cell death [80]. Plant defensins, including AMPs, are known to interact with glucosylceramides within fungal membranes to induce membrane permeabilization, ultimately leading to fungal cell death [81]. An antimicrobial protein gene (Ace-AMP1) isolated from onion seeds that possessed higher plant pathogenic inhibition activity, was introduced into the Rosa hybrida cv. Carefree Beauty. The transgenic rose, overexpressing the Ace-AMP1 gene, was developed to induce fungal disease resistance, and the rose showed enhanced resistance to powdery mildew disease [82]. Furthermore, the transgenic rose, overexpressing antifungal genes such as class II chitinase and type I ribosome inhibiting protein (RIP), exhibited reduced susceptibility to fungal diseases [75]. Transgenic rose plants possessing a high level of expression of the 
rice chitinase gene displayed improved resistance to powdery mildew [83]. Previous studies suggested that loss-of-function mutations in mildew resistance locus- o $(\mathrm{Mlo})$ genes confer broad-spectrum resistance against pathogens, and hence, $M l o$ genes can confer an effective race-independent resistance in several crops $[84,85]$. Although the mechanism underlying $M L O$-based disease resistance remains unclear, some of their family members function by regulating fungal-penetration resistance by controlling vesicle fusion events [86]. Indeed, Qiu et al. (2015) generated transgenic Rosa multiflora expressing an antisense RhMLO1 that exhibited enhanced resistance to powdery mildew [87]. Xiang et al. (2019) recently identified two MLO members, $R g M L O 6$ and RlMLO7, that are potential candidate genes that can induce resistance to powdery mildew in Rosa species [88]. Black spot disease is another major fungal disease caused by Diplocarpon rosae Wolf, a hemibiotrophic ascomycete. It is one of the most devastating and widespread fungal diseases of the rose and leads to huge economic losses [89]. Black and brown spots appear on leaves as the representative symptoms of the disease and, eventually, immature leaves become weak and fall from the plant. Defoliation decreases the photosynthetic area of plants, thus leading to a reduction in plant vibrance, thereby drastically lowering its ornamental value. A rice chitinase gene introduced into the rose-susceptible cultivar 'Glad Tidings' by particle bombardment conferred reduced susceptibility to black spot disease [90]. The black-spot-susceptible rose cultivars 'Heckenzauber' and 'Pariser Charme' were transformed with chitinases, glucanases, and RIPs from barley, and the transgenic plants exhibited a reduction of $40 \%$ in black spot diseases compared to that of the control [75]. Terefe-Ayana et al. (2011) reported the $R d r 1$ locus as important for resistance to black spot diseases in roses, and this is useful for applications in rose breeding, including the use of genetic modification technology [56]. Recently, transcriptomic analyses of roses responding to the two fungal pathogens, $D$. rosae (black spot) and P. pannosa (powdery mildew), demonstrated that the genes related to common defense mechanisms were upregulated in black spot and that those related to photosynthesis and cell-wall modification were downregulated for powdery mildew, thus implying that distinct cellular responses are stimulated by different fungal pathogens, even in the same host [91]. B. cinerea is a notorious fungal pathogen responsible for gray mold disease in roses. B. cinerea conidia secretes phytotoxins and secondary metabolites during penetration into the host epidermis, ultimately causing host cell death [92]. Necrotic local lesions on petals are the major symptoms of $B$. cinerea infection in roses, and these infections rapidly develop during postharvest transport when the flowers are packed in boxes with a high relative humidity [93]. Petals are economically important organs, and when they are damaged, this causes large commercial losses in the rose industry. Despite its economic importance as a predominant pathogen, studies examining $B$. cinerea infections in roses are limited to the comparisons of pathogen behavior in model plants such as Arabidopsis [94]. Recently, transcriptomic analyses of rose petals infected by B. cinerea determined that RcERF099, a gene that encodes member of the AP2/ERF transcription factor family, is involved in the regulation of resistance against $B$. cinerea in rose flowers, and this finding can provide a stepping stone for further studies aiming to improve gray mold disease resistance in roses [95].

\subsection{Chrysanthemum}

The chrysanthemum (Chrysanthemum morifolium) is one of the most economically important and highly favored floricultural crops in terms of ornamental market value, and is used as a cut flower, pot flower, and garden plant [96]. It is a herbaceous perennial species belonging to Asteraceae and some of the family members, such as Chrysanthemum morifolium and Chrysanthemum indicum, have been widely used for medicinal tea and/or as materials in the cosmetic industry [97]. Chrysanthemums possess a higher ornamental value due to their abundant diversity in floral color and shape, which is the result of their large genome complexity and the allohexaploid background of the cultivated chrysanthemum [98]. Chrysanthemums are affected by a wide range of fungal diseases, including leaf spots, gray mold, rusts, and powdery mildew. A major aspect of chrysanthemum crop 
production relies on chemical control and this process exhibits only ephemeral benefits. The narrow genetic pool and complex hexaploid genome are major limitations for classical breeding to introduce disease-resistant traits. Thus, genetic transformation is a potential alternative to hasten the production of disease-resistant genotypes with improved targeted traits [99]. Leaf spots in chrysanthemums are caused by different fungi, including the Alternaria species, Septoria chrysanthemi, Septoria chrysanthemella, Septoria obesa, and Cercospora chrysanthemi. Symptoms appear on leaves as yellowish spots that gradually become dark brown and black, ultimately leading to premature leaf losses and consequent yield losses. Transgenic chrysanthemums, overexpressing polygalacturonase-inhibiting protein (PGIP) from Prunus mumei, exhibited improved resistance to Alternaria leaf spot [100]. Hairpins are pathogenic molecules encoded by hrp genes that can induce plant resistance by activating defense-signaling cascades. Overexpression of one such $h r p$ gene, $h p a G_{X o o}$, conferred increased resistance to Alternaria tenuissima in chrysanthemums [101], and the introduction of the rice chitinase gene (chiII) in chrysanthemums cv. Snowball resulted in increased resistance to leaf spot caused by Septoria obesa [102]. Gray mold disease caused by $B$. cinerea is the predominant fungal disease in chrysanthemums. Leaves from infected plants possess brown water-soaked spots and the infected parts are covered with a grayishbrown, powdery mass of spores. Takatsu et al. (1999) produced transgenic chrysanthemum lines overexpressing a rice chitinase gene ( $R C C 2)$, which showed enhanced resistance to gray mold disease [103]. Similarly, chrysanthemums cv. Shinba, overexpressing N-methyl transferase genes such as CaXMT1, CaMXMT1, and CaDXMT1, exhibited increased resistance to $B$. cinerea. Leaves from the transgenic lines produced 2.5-fold higher levels of salicylic acid compared to that of the wild type, thus leading to delayed occurrence of the disease and reduced disease index [104]. These N-methyl transferases methylate xanthosine derivatives can be used to yield caffeine that indirectly stimulates the defense network, thus inducing the systemic acquired resistance in the host plant [105]. White rust disease is caused by Puccinia horiana Henn. and is one of the most destructive fungal diseases in chrysanthemums. It spreads rapidly under humid conditions in greenhouses, ultimately resulting in considerable economic losses [106]. Symptoms typically appear on the adaxial leaf surface as pale green to yellow spots, that then exhibit raised buff or pinkish pustules. Stems, bracts, flower buds, and florets are infected in susceptible cultivars [107]. Transgenic chrysanthemums, overexpressing the $C r y 1 \mathrm{Ab}$ gene from Bacillus thuringiensis and a modified sarcotoxin IA gene from Sarcophaga peregrine (msar), exhibited a stronger resistance to white rust caused by Puccinia horiana and also exhibited Helicoverpa armigera resistance [108]. A recent study demonstrated that CmWRKY15-1, which encodes a WRKY transcription factor, plays a key role in the resistance to white rust caused by $P$. horiana by regulating the salicylic acid-mediated disease-resistance signaling pathway in chrysanthemums [109].

\subsection{Petunia}

Petunia hybrida is a popular ornamental hybrid with diverse floral colors and morphologies. It belongs to the Solanaceae family and is native to South America. Petunias possess a well-established record of being a model system for studying the molecular, genetic, and ecological factors that determine flower development $[110,111]$ and can be affected by wilting, discoloration, and plant death. Verticillium wilt is caused by Verticillium albo-atrum that attacks the plant from the soil through a water-transport system. The infected leaves eventually turn brown and drop off from the plant. The petunia is infected by powdery mildew pathogens such as Podosphaera xanthii, Golovinomyces orontii, and Oidium longipes. Symptoms can be identified according to powdery white spores on the foliage [112]. Petunias are severely affected by B. cinerea, a foliar leaf pathogen that causes gray mold and leaf blight [113]. Transgenic Petunia hybrida, overexpressing the endochitinase gene from Trichoderma harzianum, alone or in combination with osmotin, exhibited resistance to $B$. cinerea [114]. Khan et al. (2011) developed transgenic petunia plants overexpressing the wasabi defensin (WD) gene from Wasabia japonica [115]. Expression of the AMP defensin increased resistance to $B$. cinerea in marker-free transgenic petunias. Similarly, transgenic 
Petunia hybrida plants, overexpressing the synthetic chitinase gene Nakamura Ikuo Chitinase (NIC) encoding Chitinase1 protein of Rhizopus oligosporus, exhibited enhanced resistance to B. cinerea [116]. Recently, reduced levels of PhMLO1 expression achieved by introducing a PhMLO1 RNAi construct resulted in improved resistance to powdery mildew in petunias. However, PhMLO1 knockdown resulted in pleiotropic effects on petunia growth and development that may have a negative effect on the further development of strategies to create powdery mildew resistance by RNAi in petunias [117].

\subsection{Lily}

Lilies (Lilium spp.), cultivated as a flower crop and potted plant, are one of the most popular ornamental plants. Lilies are affected by major fungal diseases, including gray mold caused by Botrytis elliptica. Symptoms are characterized by oval or circular yellowish or red spots on the leaves. Infected floral buds become shriveled and distorted, and the plants can die, depending on the severity of the disease [118]. Bulb rot in lilies caused by Fusarium oxysporum produces the initial symptoms of the plant's foliage yellowing and wilting. Even though the bulbs appear healthy, the roots develop a reddish-colored decay in the tips. The plants become stunted with yellow foliage and rotted scales. The transgenic Lilium oriental 'Star Gazer', developed by overexpressing the $\mathrm{RCH10}$ chitinase gene, conferred resistance to B. cinerea [119]. More recently, microRNA159 from Lilium regale (lre-miR159) has been reported to confer resistance to gray mold caused by B. elliptica in transgenic Arabidopsis by repressing the expression of its target gene $\operatorname{LrGAMYB}$ [120]. Additionally, overexpression of the LsGRP1 gene encoding a class II glycine-rich protein from Lilium, conferred resistance to B. cinerea in Arabidopsis. The authors determined that LsGRP1 plays a role as a pathogen-inducible switch to allow for activation of the immune response in the plant and to consequently induce fungal apoptosis [121]. Several candidate genes conferring resistance to fungal pathogens have been identified in lilies. Sun et al. (2016) reported that transgenic petunia plants, overexpressing the ATP-binding cassette transporter gene $L r A B C F 1$ from $L$. regale, displayed increased resistance to $B$. cinerea and RNA viruses (cucumber mosaic virus and tobacco rattle virus) in petunias [122]. Similarly, the glutathione-S-transferase gene introduced by L. regale Wilson induced resistance to $F$. oxysporum in transgenic tobacco [123] and the overexpression of a 14-3-3 gene from $L$. regale Wilson conferred resistance to Fusarium wilt in transgenic tobacco [124]. Various genes induced in response to an $F$. oxysporum infection have been identified in $L$. regale Wilson [125-127] and the identified candidates serve as valuable resources to develop improved resistance to fungal pathogens in lily cultivars.

\subsection{Other Ornamentals}

Various ornamental plants, including the carnation, gladiolus, scented geraniums, African violets, and bentgrass, have been transformed to possess fungal disease resistance. Transgenic carnation harboring different combinations of $P R-1$, osmotin, or chitinase genes have been developed to induce resistance to F. oxysporum [128]. Resistance to Fusarium wilt was generated in transgenic carnation by transforming the bacterial chitinase gene from Serratia marsecens [129]. Later, the jasmonate methyl transferase gene was introduced into carnation for Fusarium resistance [130]. Transgenic gladiolus 'Peter Pears', developed by transforming with a synthetic antimicrobial peptide gene (D4E1), exhibited enhanced resistance to F.oxysporum [131]. Kamo et al. (2016) demonstrated that cell extracts from the transgenic gladiolus, overexpressing a fungal exochitinase, endochitinase, or a bacterial chloroperoxidase, could inhibit the growth of F. oxysporum [132]. The Ace-AMP1 gene was transformed in scented geraniums to provide resistance to $B$. cinerea, and the expression level of the Ace-AMP1 protein was proportionally correlated with enhanced resistance to Botrytis sporulation [133]. Glucanase and chitinase genes were transformed into African violets to induce resistance to F. oxysporum and Pythium [134]. Transgenic glufosinate-resistant bentgrass (Agrostis spp.) plants, developed for herbicide resistance, exhibited increased resistance to fungal pathogens, including Rhizoctonia solani and Sclerotinia homoeocarpa, after 
a spraying with glufosinate herbicide, thus indicating that the nonselective herbicide glufosinate can be used to suppress some fungal pathogens in transgenic glufosinate-resistant bentgrasses [135]. SNP markers for linkage mapping and the transcripts that may be involved in Botrytis resistance have been recently identified in gerbera, and these findings may be useful for further studies of disease resistance [66]. Moreover, transcriptomic analyses performed in gerbera revealed candidate genes for resistance to powdery mildew, and these could provide valuable resources for developing powdery mildew-resistant gerbera cultivars [136]. Recent reports detailing the enhancement of fungal disease resistance in various ornamental plants are listed in Table 2.

Table 2. Recent advances in the genetic engineering of various ornamental crops for fungal disease resistance.

\begin{tabular}{|c|c|c|c|}
\hline Crop & Gene & Disease Resistance & Reference \\
\hline \multirow{6}{*}{$\begin{array}{c}\text { Rose } \\
(\text { Rosa hybrida) }\end{array}$} & Ace-AMP1 & $\begin{array}{c}\text { powdery mildew } \\
\text { (Podosphaera pannosa) }\end{array}$ & {$[82]$} \\
\hline & rice chitinase & $\begin{array}{c}\text { powdery mildew } \\
\text { (P. pannosa) }\end{array}$ & [83] \\
\hline & RhMLO1, RgMLO6, RlMLO7 & $\begin{array}{l}\text { powdery mildew } \\
(\text { P. pannosa })\end{array}$ & {$[87,88]$} \\
\hline & rice chitinase & $\begin{array}{c}\text { black spot } \\
\text { (Diplocarpon rosae) }\end{array}$ & {$[90]$} \\
\hline & chitinases, glucanases, and RIPs & $\begin{array}{l}\text { black spot } \\
\text { (D. rosae) }\end{array}$ & {$[75]$} \\
\hline & $R d r 1$ & $\begin{array}{l}\text { black spot } \\
\text { (D. rosae) }\end{array}$ & [56] \\
\hline \multirow{7}{*}{$\begin{array}{c}\text { Chrysanthemum } \\
\text { (Chrysanthemum morifolium) }\end{array}$} & PGIP & $\begin{array}{c}\text { Alternaria leaf spot } \\
\text { (Septoria chrysanthemi) }\end{array}$ & [100] \\
\hline & hairpinXoo & $\begin{array}{c}\text { leaf spot } \\
\text { (Alternaria tenuissima) }\end{array}$ & [101] \\
\hline & chill & $\begin{array}{c}\text { leaf spot } \\
\text { (Septoria obesa) }\end{array}$ & [102] \\
\hline & RCC2 & $\begin{array}{l}\text { gray mold } \\
\text { (B. cinerea) }\end{array}$ & [103] \\
\hline & CaXMT1, CaMXMT1, CaDXMT1 & $\begin{array}{l}\text { gray mold } \\
\text { (B. cinerea) }\end{array}$ & {$[104]$} \\
\hline & Cry $1 A b$ and sarcotoxin IA & $\begin{array}{l}\text { white rust } \\
\text { (P. horiana) }\end{array}$ & {$[108]$} \\
\hline & CmWRKY15-1 & white rust & [109] \\
\hline \multirow{3}{*}{$\begin{array}{c}\text { Petunia } \\
(\text { Petunia hybrida })\end{array}$} & endochitinase and osmotin & $\begin{array}{l}\text { gray mold } \\
\text { (B. cinerea) }\end{array}$ & [114] \\
\hline & WD (Wasabi defensin) & $\begin{array}{l}\text { gray mold } \\
\text { (B. cinerea) }\end{array}$ & [115] \\
\hline & NIC (Nakamura Ikuo Chitinase) & $\begin{array}{l}\text { gray mold } \\
\text { (B. cinerea) }\end{array}$ & [116] \\
\hline \multirow{2}{*}{$\begin{array}{l}\text { Lily } \\
\text { (Lilium) }\end{array}$} & RCH10 chitinase & $\begin{array}{l}\text { gray mold } \\
\text { (B. cinerea) }\end{array}$ & [119] \\
\hline & Ire-miR159 & $\begin{array}{l}\text { gray mold } \\
\text { (B. elliptica) }\end{array}$ & [120] \\
\hline \multirow{3}{*}{$\begin{array}{c}\text { Carnation } \\
\text { (Dianthus caryophyllus) }\end{array}$} & $\begin{array}{l}\text { PR-1, osmotin, } \\
\text { chitinase }\end{array}$ & $\begin{array}{l}\text { Fusarium wilt } \\
\text { (F. oxysporum) }\end{array}$ & {$[128]$} \\
\hline & bacterial chitinase & $\begin{array}{l}\text { Fusarium wilt } \\
\text { (F. oxysporum) }\end{array}$ & [129] \\
\hline & $\begin{array}{l}\text { jasmonate methyl } \\
\text { transferase }\end{array}$ & $\begin{array}{l}\text { Fusarium wilt } \\
\text { (F. oxysporum) }\end{array}$ & [130] \\
\hline
\end{tabular}


Table 2. Cont.

\begin{tabular}{cccc}
\hline Crop & Gene & Disease Resistance & Reference \\
\hline $\begin{array}{c}\text { Gladioulus } \\
\text { (Gladiolus communis) }\end{array}$ & $\begin{array}{c}\text { D4E1 } \\
\text { Fungal exochitinase, endochitinase, } \\
\text { bacterial chloroperoxidase }\end{array}$ & $\begin{array}{c}\text { Fusarium wilt } \\
\text { (F.oxysporum) } \\
\text { Fusarium wilt } \\
\text { (F. oxysporum) }\end{array}$ & [131] \\
\hline $\begin{array}{c}\text { Geranium } \\
\text { (Pelargonium graveolens L. Herit.) }\end{array}$ & Ace-AMP1 & $\begin{array}{c}\text { gray mold } \\
\text { (B. cinerea) }\end{array}$ & [133] \\
\hline $\begin{array}{c}\text { African violets } \\
\text { (Saintpaulia ionantha) }\end{array}$ & $\begin{array}{c}\text { glucanase and } \\
\text { chitinase }\end{array}$ & Fusarium and Pythium & {$[134]$} \\
\hline
\end{tabular}

\section{Host-Induced Gene Silencing (HIGS) and Spray-Induced Gene Silencing (SIGS) Used to Control Fungal Pathogens}

Originally, RNAi was identified as a biological gene-silencing mechanism that involves double-stranded RNA-mediated sequence-specific mRNA degradation, and this technique was subsequently applied to investigate gene function and to genetically engineer plants for beneficial purposes. Suppressing gene expression by silencing the target RNA plays a key role not only in exploring gene function but also in combating plant pathogens. RNAi-based pathogen control is a powerful alternative to synthetic fungicides for crop protection against fungal diseases. These strategies include HIGS and SIGS that are both environmental-friendly and can provide scope for controlling plant diseases [19,137-139]. HIGS functions are based on RNAi and involve the expression of sequence-specific doublestranded RNAs (dsRNAs) in the host plant to thereby silence its target genes [140]. The mechanism of HIGS includes the transformation of the host plant with either a dsRNA or a hairpin-structured dsRNA construct containing the targeted pathogen gene. The generation of small interfering RNAs (siRNAs), homologous to the target mRNA, leads to degradation of the target mRNAs within the pathogen, thus protecting the host plant from the pathogen $[137,138]$. HIGS has been extensively applied to various important crops to effectively control fungal pathogens. For example, HIGS has been successfully applied in tobacco plants to fight against the necrotrophic fungal pathogen Sclerotinia sclerotiorum by silencing the fungal chitin synthase (chs) gene. Transgenic tobacco lines exhibited a reduction in disease severity within $72 \mathrm{~h}$, and this was correlated with the presence of detectable siRNAs in these plants. Thus, HIGS prevents the expression of endogenous fungal genes to thereby increase disease resistance [141]. Similarly, HIGS has been implemented in horticultural crops to control fungal pathogens, including $F$. oxysporum that causes Fusarium wilt in banana; Verticillium dahliae that causes verticillium wilt in tomato; and the oomycete pathogen Phytophthera infestans that causes late blight in potato [142-144]. Other crops that have been successfully employed for transgenic studies include wheat and barley to combat fungal pathogens such as Puccinia species; Fusarium species; Blumeria graminis; and Magnaporthe oryzae in rice [18,145-151]. Active application of HIGS to ornamental crops helps to produce varieties that are resistant to fungal pathogens.

In addition to the production of RNA-silencing molecules in planta as observed in HIGS, SIGS can also be used by spray-applied biopesticides to control the pathogen. Although HIGS is effective against various pathogens in different crops, it can only be applied to crops that are available for efficient transformation [152]. SIGS is a non-transformative approach for protecting plants from diseases. Externally synthesized dsRNAs targeting a specific pathogen gene are sprayed onto the surfaces of the host plant. This is followed by either the host plant absorbing the dsRNAs and the subsequent induction of RNAi machinery, where the dsRNAs or siRNAs are further transferred to fungal cells to modulate the fungal RNAi machinery, or by the fungal cells on the host plant directly uptaking the sprayed dsRNAs to trigger the fungal RNAi machinery directly. The RNAi machinery in the fungal pathogen silences the target gene to thereby enhance the resistance of the 
host plant to the disease $[19,139,152]$. SIGS has been employed in different crops and has been observed to be efficient in combating fungal diseases. Successful application of SIGS in controlling B. cinerea and its phytopathogenic fungus Sclerotinia sclerotiorum has been reported in canola plants [153]. The SIGS strategy was also applied to barley by spraying CYP3-dsRNAs onto barley leaves, thus conferring resistance to Fusarium graminearum after inoculation [19]. Application of SIGS in ornamental plants is still in its infancy, and only two studies have been reported in the Dendrobium orchid and rose. In the Dendrobium hybrid, direct application of crude bacterial extract, consisting of MYB1-dsRNAs, onto flower buds led to the suppression of $D h M y b 1$ expression, ultimately resulting in altered floral epidermal cell morphology [154]. Notably, Wang et al. (2016) revealed that gray mold caused by B. cinerea in roses can be controlled through the use of SIGS by spraying dsRNAs or small RNAs (sRNAs) targeting the Bc-DCL1 and Bc-DCL2 that are primarily responsible for the deliverable sRNA production, to allow for the silencing host immunity genes to function [152]. Furthermore, treatment with tobacco RNA extracts containing $B c$-DCL1/2-sRNAs on rose flowers reduces gray mold disease symptoms caused by $B$. cinerea. Both HIGS and SIGS represent promising and sustainable future technologies that offer eco-friendly crop protection and efficient strategies to study fungal pathogen defense in ornamental plants.

RNAi-based biopesticides target pathogens with specificity and accuracy and have enormous potential as an alternative to chemical-based control methods. However, RNAi has its own limitations to overcome including the stable delivery of the topically applied dsRNA and the duration of its pathogen protection. Additionally, the generalized risk of RNAi, similar to any genetic modification technology of plants, has the potential to adversely impact human health and the environment. Unlike the other crop protection methods, evident risks to human health by RNAi technology appear minimal, as the uptake of these dsRNAs involves multiple barriers, ubiquitous presence of dsRNAs in animals, and general consumption of dsRNA from plant material [155]. Usually, unintended impacts of RNAi to the environment are case-specific and mostly in the species closely related to the target [156]. Since the RNAi specificity depends upon the sequence identity between siRNAs and mRNA targets, there is a risk of off-target effect which may lead to the silencing of other transcripts containing sufficient sequence identity [157]. This off-target may occur even in the host plant [158]. This can be minimized by careful design of dsRNAs on the target genes through identifying and avoiding the contagious matches to ensure the reduction in homology to off-target transcripts [159].

\section{Conclusions and Future Prospects}

Global commercial demand for ornamental crops is steadily rising. Approximately one third of the global ornamental market value comprises of cut flowers. Developing and introducing novel cultivars that possess the most desired ornamental attributes is vital in this ever-growing dynamic sector. Fungal diseases are considered to be the greatest threat to ornamental plants, contributing to huge losses in the host. Ornamental crops cannot tolerate fungal disease damage, as diseases directly affect the visual quality of cut flowers, an attribute that is critical for the esthetic value of attractive ornamental plants. Hence, the ultimate goal is to accelerate the development of novel cultivars that possess resistance to fungal diseases. Molecular breeding for fungal disease resistance in ornamental crops is lagging, primarily due to their complex genomes. Advances in next-generation sequencing (NGS) and multi-omics technologies have made it possible to obtain complete genome sequence information that can expedite the identification of a large number of molecular markers used for QTL mapping and GWAS. These data would be useful for exploring the complicated genetic mechanisms underlying fungal disease resistance. This enables the mining of candidate genes that are associated with disease-resistant traits and related pathways. The identified genes can be applied to genetic engineering to develop transgenic plants exhibiting enhanced resistance, a trait that constitutes a key component of disease management. Furthermore, genome editing tools such as CRISPR/Cas9 systems possess 
the potential to rapidly improve complex disease-resistance traits by editing either genes for susceptibility, or the genome of the pathogen itself [20]. However, the application of genome editing tools for fungal disease resistance in ornamental plants is still in its early stages. Due to the higher specificity, ease, and reproducibility of these tools, this breakthrough technology holds tremendous potential to enhance disease resistance in ornamental crops in the near future. Additionally, recent innovative strategies such as HIGS and SIGS have emerged as promising approaches to crop protection that are sustainable and environmentally friendly [140]. These approaches utilize the ability of dsRNA to silence the expression of target genes in plant pathogens. In particular, as SIGS does not require genetic transformation, it can be efficiently used for crop protection in ornamental plants. The combination of HIGS with the CRISPR/Cas9 approach will enhance fungal disease resistance in ornamental plants. A comprehensive illustration of breeding strategies to develop ornamental crops possessing improved fungal disease resistance is presented in Figure 2.

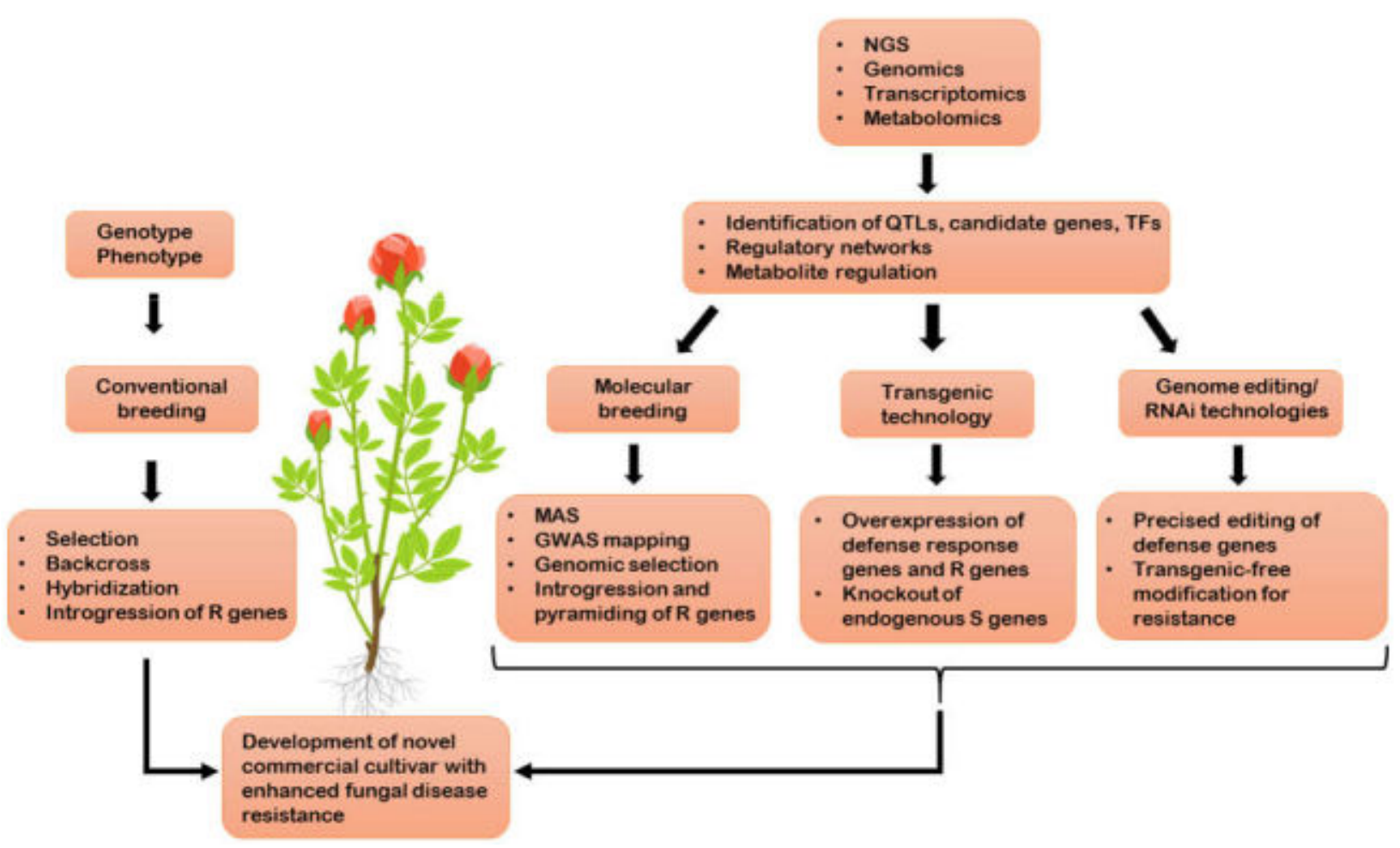

Figure 2. The comprehensive illustration of different strategies, integrating conventional and advanced breeding technologies to develop novel ornamental cultivars which possess enhanced fungal disease resistance traits.

Author Contributions: M.M., J.-A.J. and S.J. conceived the present work; M.M., J.-A.J. and S.J. drafted the manuscript; M.-S.A. and H.-Y.S. collected the background information; O.-K.K., J.-A.J., and S.J. revised the manuscript. All authors have read and agreed to the published version of the manuscript.

Funding: This work was financially supported by the National Institute of Horticulture and Herbal Science, RDA, Korea, under the project grant PJ01098202 and in part by the World Vegetable Center Korea Office budget (WKO \#10000379) and the long-term strategic donors to the World Vegetable Center: Republic of China (Taiwan), UK aid from the UK government, United States Agency for International Development (USAID), Australian Center for International Agricultural Research (ACIAR), Germany, Thailand, Philippines, Korea, and Japan.

Institutional Review Board Statement: Not applicable.

Informed Consent Statement: Not applicable. 
Data Availability Statement: All the data is contained within the article.

Conflicts of Interest: The authors declare no conflict of interest.

\section{References}

1. Lecomte, C.; Alabouvette, C.; Edel-Hermann, V.; Robert, F.; Steinberg, C. Biological control of ornamental plant diseases caused by Fusarium oxysporum: A review. Biol. Cont. 2016, 101, 17-30. [CrossRef]

2. Chandler, S.F.; Sanchez, C. Genetic modification; the development of transgenic ornamental plant varieties. Plant Biotechnol. J. 2012, 10, 891-903. [CrossRef] [PubMed]

3. Royal FloraHolland in Facts and Figures. 2019 Annual Report. Available online: https://www.royalfloraholland.com/en (accessed on 15 March 2021).

4. Strange, R.N.; Scott, P.R. Plant disease: A threat to global food security. Annu. Rev. Phytopathol. 2005, 43, 83-116. [CrossRef]

5. Parisi, C.; Tillie, P.; Rodríguez-Cerezo, E. The global pipeline of GM crops out to 2020. Nat. Biotechnol. 2016, 34, 31-36. [CrossRef]

6. Punja, Z.K. Recent developments toward achieving fungal disease resistance in transgenic plants. Canad. J. Plant Pathol. 2006, 28, S298-S308. [CrossRef]

7. Fisher, M.C.; Henk, D.A.; Briggs, C.J.; Brownstein, J.S.; Madoff, L.C.; McCraw, S.L.; Gurr, S.J. Emerging fungal threats to animal, plant and ecosystem health. Nature 2012, 484, 186-194. [CrossRef]

8. Alexopoulos, C.J.; Mims, C.W.; Blackwell, M. Introductory Mycology; John Wiley and Sons: New York, NY, USA, 1996.

9. Doehlemann, G.; Ökmen, B.; Zhu, W.; Sharon, A. Plant pathogenic fungi. In The Fungal Kingdom; John Wiley and Sons: Washington, DC, USA, 2017; pp. 701-726.

10. Gavrilescu, M.; Chisti, Y. Biotechnology-A sustainable alternative for chemical industry. Biotechnol. Adv. 2005, 23, 471-499. [CrossRef]

11. Hammond, J.; Hsu, H.-T.; Huang, Q.; Jordan, R.; Kamo, K.; Pooler, M. Transgenic approaches to disease resistance in ornamental crops. J. Crop Imp. 2006, 17, 155-210. [CrossRef]

12. Jeseničnik, T.; Štajner, N.; Radišek, S.; Jakše, J. RNA interference core components identified and characterised in Verticillium nonalfalfae, a vascular wilt pathogenic plant fungi of hops. Sci. Rep. 2019, 9, 1-12.

13. Hammond-Kosack, K.E.; Parker, J.E. Deciphering plant-pathogen communication: Fresh perspectives for molecular resistance breeding. Curr. Opin. Biotechnol. 2003, 14, 177-193. [CrossRef]

14. Michelmore, R.W. The impact zone: Genomics and breeding for durable disease resistance. Curr. Opin. Plant Biol. 2003, 6, 397-404. [CrossRef]

15. Debener, T. Current strategies and future prospects of resistance breeding in ornamentals. Acta Hortic. 2009, 836, 125-130. [CrossRef]

16. Arens, P.; Bijman, P.; Tang, N.; Shahin, A.; Van Tuyl, J. Mapping of disease resistance in ornamentals: A long haul. Acta Hortic. 2012, 953, 231-237. [CrossRef]

17. Parmar, N.; Singh, K.H.; Sharma, D.; Singh, L.; Kumar, P.; Nanjundan, J.; Khan, Y.J.; Chauhan, D.K.; Thakur, A.K. Genetic engineering strategies for biotic and abiotic stress tolerance and quality enhancement in horticultural crops: A comprehensive review. 3 Biotech 2017, 7, 1-35. [CrossRef]

18. Nowara, D.; Gay, A.; Lacomme, C.; Shaw, J.; Ridout, C.; Douchkov, D.; Hensel, G.; Kumlehn, J.; Schweizer, P. HIGS: Host-induced gene silencing in the obligate biotrophic fungal pathogen Blumeria graminis. Plant Cell 2010, 22, 3130-3141. [CrossRef] [PubMed]

19. Koch, A.; Biedenkopf, D.; Furch, A.; Weber, L.; Rossbach, O.; Abdellatef, E.; Linicus, L.; Johannsmeier, J.; Jelonek, L.; Goesmann, A. An RNAi-based control of Fusarium graminearum infections through spraying of long dsRNAs involves a plant passage and is controlled by the fungal silencing machinery. PLoS Pathog. 2016, 12, e1005901. [CrossRef]

20. Mushtaq, M.; Sakina, A.; Wani, S.H.; Shikari, A.B.; Tripathi, P.; Zaid, A.; Galla, A.; Abdelrahman, M.; Sharma, M.; Singh, A.K. Harnessing genome editing techniques to engineer disease resistance in plants. Front. Plant Sci. 2019, 10, 550. [CrossRef] [PubMed]

21. Schäfer, W. Molecular mechanisms of fungal pathogenicity to plants. Ann. Rev. Phytopathol. 1994, 32, 461-477. [CrossRef]

22. Nicholson, R.L.; Epstein, L. Adhesion of fungi to the plant surface. In The Fungal Spore and Disease Initiation in Plants and Animals; Plenum Press: New York, NY, USA, 1991; pp. 3-23.

23. Hamer, J.E.; Howard, R.J.; Chumley, F.G.; Valent, B. A mechanism for surface attachment in spores of a plant pathogenic fungus. Science 1988, 239, 288-290. [CrossRef]

24. DeZwaan, T.M.; Carroll, A.M.; Valent, B.; Sweigard, J.A. Magnaporthe grisea pth11p is a novel plasma membrane protein that mediates appressorium differentiation in response to inductive substrate cues. Plant Cell 1999, 11, 2013-2030. [CrossRef] [PubMed]

25. Wilson, R.A.; Talbot, N.J. Under pressure: Investigating the biology of plant infection by Magnaporthe oryzae. Nat. Rev. Microbiol. 2009, 7, 185-195. [CrossRef]

26. Howard, R.J.; Ferrari, M.A.; Roach, D.H.; Money, N.P. Penetration of hard substrates by a fungus employing enormous turgor pressures. Proc. Natl. Acad. Sci. USA 1991, 88, 11281-11284. [CrossRef] [PubMed]

27. Chisholm, S.T.; Coaker, G.; Day, B.; Staskawicz, B.J. Host-microbe interactions: Shaping the evolution of the plant immune response. Cell 2006, 124, 803-814. [CrossRef]

28. Andersen, E.J.; Ali, S.; Byamukama, E.; Yen, Y.; Nepal, M.P. Disease resistance mechanisms in plants. Genes 2018, 9, 339. [CrossRef] 
29. Dodds, P.N.; Rathjen, J.P. Plant immunity: Towards an integrated view of plant-pathogen interactions. Nat. Rev. Genet. 2010, 11, 539-548. [CrossRef] [PubMed]

30. Uma, B.; Rani, T.S.; Podile, A.R. Warriors at the gate that never sleep: Non-host resistance in plants. J. Plant Physiol. 2011, 168, 2141-2152. [CrossRef] [PubMed]

31. Jones, J.D.; Dangl, J.L. The plant immune system. Nature 2006, 444, 323-329. [CrossRef] [PubMed]

32. Dong, O.X.; Ronald, P.C. Genetic engineering for disease resistance in plants: Recent progress and future perspectives. Plant Physiol. 2019, 180, 26-38. [CrossRef]

33. Thomma, B.P.; Cammue, B.P.; Thevissen, K. Plant defensins. Planta 2002, 216, 193-202. [CrossRef]

34. Ahuja, I.; Kissen, R.; Bones, A.M. Phytoalexins in defense against pathogens. Trends Plant Sci. 2012, 17, 73-90. [CrossRef]

35. Kachroo, A.; Vincelli, P.; Kachroo, P. Signaling mechanisms underlying resistance responses: What have we learned, and how is it being applied? Phytopathology 2017, 107, 1452-1461. [CrossRef] [PubMed]

36. Boutrot, F.; Zipfel, C. Function, discovery, and exploitation of plant pattern recognition receptors for broad-spectrum disease resistance. Ann. Rev. Phytopathol. 2017, 55, 257-286. [CrossRef] [PubMed]

37. Tyagi, S.; Kumar, R.; Kumar, V.; Won, S.Y.; Shukla, P. Engineering disease resistant plants through CRISPR-Cas9 technology. GM Crops Food 2021, 12, 125-144. [CrossRef] [PubMed]

38. Hamel, L.-P.; Nicole, M.-C.; Duplessis, S.; Ellis, B.E. Mitogen-activated protein kinase signaling in plant-interacting fungi: Distinct messages from conserved messengers. Plant Cell 2012, 24, 1327-1351. [CrossRef] [PubMed]

39. Silva, M.S.; Arraes, F.B.M.; de Araújo Campos, M.; Grossi-de-Sa, M.; Fernandez, D.; de Souza Cândido, E.; Cardoso, M.H.; Franco, O.L.; Grossi-de-Sa, M.F. Potential biotechnological assets related to plant immunity modulation applicable in engineering disease-resistant crops. Plant Sci. 2018, 270, 72-84. [CrossRef]

40. González, G.; Fuentes, L.; Moya-León, M.A.; Sandoval, C.; Herrera, R. Characterization of two PR genes from Fragaria chiloensis in response to Botrytis cinerea infection: A comparison with Fragaria x ananassa. Physiol. Mol. Plant Pathol. 2013, 82, 73-80. [CrossRef]

41. Silvia Sebastiani, M.; Bagnaresi, P.; Sestili, S.; Biselli, C.; Zechini, A.; Orrù, L.; Cattivelli, L.; Ficcadenti, N. Transcriptome analysis of the melon-Fusarium oxysporum f. sp. melonis race 1.2 pathosystem in susceptible and resistant plants. Front. Plant Sci. 2017, 8, 362. [CrossRef]

42. Derksen, H.; Rampitsch, C.; Daayf, F. Signaling cross-talk in plant disease resistance. Plant Sci. 2013, 207, 79-87. [CrossRef]

43. Won, S.Y.; Kim, J.S.; Kang, S.-H.; Sohn, S.-H. Current status and prospects of chrysanthemum genomics. J. Plant Biotechnol. 2016, 43, 272-280. [CrossRef]

44. Debener, T. Molecular tools for modern ornamental plant breeding and selection. Acta Hortic. 2001, 552, 121-128. [CrossRef]

45. Debener, T.; Byrne, D.H. Disease resistance breeding in rose: Current status and potential of biotechnological tools. Plant Sci. 2014, 228, 107-117. [CrossRef]

46. Byrne, D.H. Rose structural genomics. In Genetics and Genomics of Rosaceae; Springer: New York, NY, USA, 2009 ; pp. 353-379.

47. Gar, O.; Sargent, D.J.; Tsai, C.-J.; Pleban, T.; Shalev, G.; Byrne, D.H.; Zamir, D. An autotetraploid linkage map of rose (Rosa hybrida) validated using the strawberry (Fragaria vesca) genome sequence. PLoS ONE 2011, 6, e20463. [CrossRef] [PubMed]

48. Spiller, M.; Linde, M.; Hibrand-Saint Oyant, L.; Tsai, C.-J.; Byrne, D.H.; Smulders, M.J.; Foucher, F.; Debener, T. Towards a unified genetic map for diploid roses. Theor. App. Genet. 2011, 122, 489-500. [CrossRef] [PubMed]

49. Von Malek, B.; Debener, T. Genetic analysis of resistance to blackspot (Diplocarpon rosae) in tetraploid roses. Theor. App. Genet. 1998, 96, 228-231. [CrossRef]

50. Linde, M.; Mattiesch, L.; Debener, T. Rpp1, a dominant gene providing race-specific resistance to rose powdery mildew (Podosphaera pannosa): Molecular mapping, SCAR development and confirmation of disease resistance data. Theor. Appl. Genet. 2004, 109, 1261-1266. [CrossRef]

51. Linde, M.; Hattendorf, A.; Kaufmann, H.; Debener, T. Powdery mildew resistance in roses: QTL mapping in different environments using selective genotyping. Theor. App. Genet. 2006, 113, 1081-1092. [CrossRef]

52. Hosseini Moghaddam, H.; Leus, L.; Van Huylenbroeck, J.; Van Bockstaele, E.; De Riek, J. Pathotype dependent resistance mapping for powdery mildew in a diploid rose population. Acta Hortic. 2010, 870, 103-108. [CrossRef]

53. Moghaddam, H.H.; Leus, L.; De Riek, J.; Van Huylenbroeck, J.; Van Bockstaele, E. Construction of a genetic linkage map with SSR, AFLP and morphological markers to locate QTLs controlling pathotype-specific powdery mildew resistance in diploid roses. Euphytica 2012, 184, 413-427. [CrossRef]

54. Xu, Q.; Wen, X.; Deng, X. Isolation of TIR and nonTIR NBS-LRR resistance gene analogues and identification of molecular markers linked to a powdery mildew resistance locus in chestnut rose (Rosa roxburghii Tratt). Theor. App. Genet. 2005, 111, 819-830. [CrossRef]

55. Xu, Q.; Wen, X.; Deng, X. Cloning of two classes of PR genes and the development of SNAP markers for powdery mildew resistance loci in chestnut rose (Rosa roxburghii Tratt). Mol. Breed. 2007, 19, 179-191. [CrossRef]

56. Terefe-Ayana, D.; Yasmin, A.; Le, T.L.; Kaufmann, H.; Biber, A.; Kühr, A.; Linde, M.; Debener, T. Mining disease-resistance genes in roses: Functional and molecular characterization of the Rdr1 locus. Front. Plant Sci. 2011, 2, 35. [CrossRef]

57. Kaufmann, H.; Qiu, X.; Wehmeyer, J.; Debener, T. Isolation, molecular characterization, and mapping of four rose MLO orthologs. Front. Plant Sci. 2012, 3, 244. [CrossRef] [PubMed] 
58. Su, J.; Jiang, J.; Zhang, F.; Liu, Y.; Ding, L.; Chen, S.; Chen, F. Current achievements and future prospects in the genetic breeding of chrysanthemum: A review. Hortic. Res. 2019, 6, 1-19. [CrossRef]

59. Park, S.K.; Arens, P.; Lim, J.H.; Jung, J.A.; Shin, H.K. Inheritance Analysis and Marker Development of White Rust Resistance in Chrysanthemum. Kor. Hortic. Soc. Acad. Pres. 2017, 10, 47. (In Korean)

60. Hirakawa, H.; Sumitomo, K.; Hisamatsu, T.; Nagano, S.; Shirasawa, K.; Higuchi, Y.; Kusaba, M.; Koshioka, M.; Nakano, Y.; Yagi, M. De novo whole-genome assembly in Chrysanthemum seticuspe, a model species of Chrysanthemums, and its application to genetic and gene discovery analysis. DNA Res. 2019, 26, 195-203. [CrossRef] [PubMed]

61. Van Heusden, A.W.; Jongerius, M.C.; Van Tuyl, J.M.; Straathof, T.P.; Mes, J. Molecular assisted breeding for disease resistance in lily. In XX International Eucarpia Symposium, Section Ornamentals, Strategies for New Ornamentals-Part II 572; ISHS: Leuven, Belgium, 2001; pp. 131-138.

62. Shahin, A.; Arens, P.; Van Heusden, S.; Van Tuyl, J.M. Conversion of molecular markers linked to Fusarium and virus resistance in Asiatic lily hybrids. Acta Hortic. 2009, 836, 131-136. [CrossRef]

63. Shahin, A.; Arens, P.; Van Heusden, A.W.; Van Der Linden, G.; Van Kaauwen, M.; Khan, N.; Schouten, H.J.; Van De Weg, W.E.; Visser, R.G.; Van Tuyl, J.M. Genetic mapping in Lilium: Mapping of major genes and quantitative trait loci for several ornamental traits and disease resistances. Plant Breed. 2011, 130, 372-382. [CrossRef]

64. Moreno-Pachon, N.M.; Leeggangers, H.A.; Nijveen, H.; Severing, E.; Hilhorst, H.; Immink, R.G. Elucidating and mining the Tulipa and Lilium transcriptomes. Plant Mol. Biol. 2016, 92, 249-261. [CrossRef] [PubMed]

65. Tang, N.; van der Lee, T.; Shahin, A.; Holdinga, M.; Bijman, P.; Caser, M.; Visser, R.G.; van Tuyl, J.M.; Arens, P. Genetic mapping of resistance to Fusarium oxysporum f. sp. tulipae in tulip. Mol. Breed. 2015, 35, 1-17. [CrossRef] [PubMed]

66. Fu, Y.; Esselink, G.D.; Visser, R.G.; van Tuyl, J.M.; Arens, P. Transcriptome analysis of Gerbera hybrida including in silico confirmation of defense genes found. Front. Plant Sci. 2016, 7, 247. [CrossRef] [PubMed]

67. Fu, Y.; Van Silfhout, A.; Shahin, A.; Egberts, R.; Beers, M.; Van der Velde, A.; Van Houten, A.; Van Tuyl, J.M.; Visser, R.G.; Arens, P. Genetic mapping and QTL analysis of Botrytis resistance in Gerbera hybrida. Mol. Breed. 2017, 37, 13. [CrossRef]

68. Tanase, K.; Nishitani, C.; Hirakawa, H.; Isobe, S.; Tabata, S.; Ohmiya, A.; Onozaki, T. Transcriptome analysis of carnation (Dianthus caryophyllus L.) based on next-generation sequencing technology. BMC Genom. 2012, 13, 1-11. [CrossRef] [PubMed]

69. Yagi, M.; Yamamoto, T.; Isobe, S.; Hirakawa, H.; Tabata, S.; Tanase, K.; Yamaguchi, H.; Onozaki, T. Construction of a reference genetic linkage map for carnation (Dianthus caryophyllus L.). BMC Genom. 2013, 14, 1-10. [CrossRef] [PubMed]

70. Yagi, M.; Kosugi, S.; Hirakawa, H.; Ohmiya, A.; Tanase, K.; Harada, T.; Kishimoto, K.; Nakayama, M.; Ichimura, K.; Onozaki, T. Sequence analysis of the genome of carnation (Dianthus caryophyllus L.). DNA Res. 2014, 21, 231-241. [CrossRef]

71. Manczinger, L.; Antal, Z.; Kredics, L. Ecophysiology and breeding of mycoparasitic Trichoderma strains. Acta Microbiol. Immunol. Hung. 2002, 49, 1-14. [CrossRef] [PubMed]

72. Wani, S.H. Inducing fungus-resistance into plants through biotechnology. Notul. Sci. Biol. 2010, 2, 14-21. [CrossRef]

73. Cairns, T. Modern Roses XII; Academic Press: New York, NY, USA, 2007.

74. Feng, L.-G.; Chen, C.; Sheng, L.-X.; Liu, P.; Tao, J.; Su, J.-L.; Zhao, L.-Y. Comparative analysis of headspace volatiles of Chinese Rosa rugosa. Molecules 2010, 15, 8390-8399. [CrossRef]

75. Dohm, A.; Ludwig, C.; Schilling, D.; Debener, T. Transformation of roses with genes for antifungal proteins to reduce their susceptibility to fungal diseases. Acta Hortic. 2002, 572, 105-111. [CrossRef]

76. Firoozabady, E.; Moy, Y.; Courtney-Gutterson, N.; Robinson, K. Regeneration of transgenic rose (Rosa hybrida) plants from embryogenic tissue. Bio/technology 1994, 12, 609-613. [CrossRef]

77. Linde, M.; Shishkoff, N. DISEASE I Powdery Mildew. In Encyclopedia of Rose Science; Elsevier: Amsterdam, The Netherlands; Academic Press: Cambridge, MA, USA; Oxford, UK, 2003; pp. 158-165. Available online: https://www.elsevier.com/books/ encyclopedia-of-rose-science/roberts/978-0-08-091797-9 (accessed on 11 March 2021).

78. Terras, F.; Schoofs, H.; De Bolle, M.; Van Leuven, F.; Rees, S.B.; Vanderleyden, J.; Cammue, B.; Broekaert, W.F. Analysis of two novel classes of plant antifungal proteins from radish (Raphanus sativus L.) seeds. J. Biol. Chem. 1992, 267, 15301-15309. [CrossRef]

79. Broekaert, W.F.; Terras, F.; Cammue, B.; Osborn, R.W. Plant defensins: Novel antimicrobial peptides as components of the host defense system. Plant Physiol. 1995, 108, 1353. [CrossRef] [PubMed]

80. Morais, J.K.S.; Gomes, V.M.; Oliveira, J.T.A.; Santos, I.S.; Da Cunha, M.; Oliveira, H.D.; Oliveira, H.P.; Sousa, D.O.; Vasconcelos, I.M. Soybean toxin (SBTX), a protein from soybeans that inhibits the life cycle of plant and human pathogenic fungi. J. Agric. Food Chem. 2010, 58, 10356-10363. [CrossRef]

81. Thevissen, K.; Ghazi, A.; De Samblanx, G.W.; Brownlee, C.; Osborn, R.W.; Broekaert, W.F. Fungal membrane responses induced by plant defensins and thionins. J. Biol. Chem. 1996, 271, 15018-15025. [CrossRef] [PubMed]

82. Li, X.; Gasic, K.; Cammue, B.; Broekaert, W.; Korban, S.S. Transgenic rose lines harboring an antimicrobial protein gene, Ace-AMP1, demonstrate enhanced resistance to powdery mildew (Sphaerotheca pannosa). Planta 2003, 218, 226-232. [CrossRef]

83. Pourhosseini, L.; Kermani, M.J.; Habashi, A.A.; Khalighi, A. Efficiency of direct and indirect shoot organogenesis in different genotypes of Rosa hybrida. Plant Cell Tissue Organ Cult. 2013, 112, 101-108. [CrossRef]

84. Consonni, C.; Humphry, M.E.; Hartmann, H.A.; Livaja, M.; Durner, J.; Westphal, L.; Vogel, J.; Lipka, V.; Kemmerling, B.; Schulze-Lefert, P. Conserved requirement for a plant host cell protein in powdery mildew pathogenesis. Nat. Gen. 2006, 38, 716-720. [CrossRef] 
85. Humphry, M.; Reinstaedler, A.; Ivanov, S.; Bisseling, T.; Panstruga, R. Durable broad-spectrum powdery mildew resistance in pea er1 plants is conferred by natural loss-of-function mutations in PsMLO1. Mol. Plant Pathol. 2011, 12, 866-878. [CrossRef]

86. Bhat, R.A.; Miklis, M.; Schmelzer, E.; Schulze-Lefert, P.; Panstruga, R. Recruitment and interaction dynamics of plant penetration resistance components in a plasma membrane microdomain. Proc. Nat. Acad. Sci. USA 2005, 102, 3135-3140. [CrossRef]

87. Qiu, X.; Wang, Q.; Zhang, H.; Jian, H.; Zhou, N.; Ji, C.; Yan, H.; Bao, M.; Tang, K. Antisense RhMLO1 gene transformation enhances resistance to the powdery mildew pathogen in Rosa multiflora. Plant Mol. Biol. Rep. 2015, 33, 1659-1665. [CrossRef]

88. Xiang, G.; Zhang, H.; Jian, H.; Yan, H.; Wang, Q.; Zhou, N.; Li, S.; Tang, K.; Qiu, X. De Novo assembly and characterization of the transcriptome of susceptible and resistant rose species in response to powdery mildew. Sci. Hortic. 2019, 257, 108653. [CrossRef]

89. Drewes-Alvarez, R. Disease/Black Spot. In Encyclopedia of Rose Science; Elsevier: Amsterdam, The Netherlands; Academic Press: Cambridge, MA, USA; Oxford, UK, 2003; pp. 148-153. Available online: https:/ / www.elsevier.com/books/encyclopedia-ofrose-science/roberts/978-0-08-091797-9 (accessed on 11 March 2021).

90. Marchant, R.; Davey, M.R.; Lucas, J.A.; Lamb, C.J.; Dixon, R.A.; Power, J.B. Expression of a chitinase transgene in rose (Rosa hybrida L.) reduces development of blackspot disease (Diplocarpon rosae Wolf). Mol. Breed. 1998, 4, 187-194. [CrossRef]

91. Neu, E.; Domes, H.S.; Menz, I.; Kaufmann, H.; Linde, M.; Debener, T. Interaction of roses with a biotrophic and a hemibiotrophic leaf pathogen leads to differences in defense transcriptome activation. Plant Mol. Biol. 2019, 99, 299-316. [CrossRef]

92. Hao, Y.; Cao, X.; Ma, C.; Zhang, Z.; Zhao, N.; Ali, A.; Hou, T.; Xiang, Z.; Zhuang, J.; Wu, S. Potential applications and antifungal activities of engineered nanomaterials against gray mold disease agent Botrytis cinerea on rose petals. Front. Plant Sci. 2017, 8 1332. [CrossRef] [PubMed]

93. Williamson, B.; Duncan, G.H.; Harrison, J.G.; Harding, L.A.; Elad, Y.; Zimand, G. Effect of humidity on infection of rose petals by dry-inoculated conidia of Botrytis cinerea. Mycol. Res. 1995, 99, 1303-1310. [CrossRef]

94. Cao, X.; Yan, H.; Liu, X.; Li, D.; Sui, M.; Wu, J.; Yu, H.; Zhang, Z. A detached petal disc assay and virus-induced gene silencing facilitate the study of Botrytis cinerea resistance in rose flowers. Hortic. Res. 2019, 6, 1-11. [CrossRef]

95. Li, D.; Liu, X.; Shu, L.; Zhang, H.; Zhang, S.; Song, Y.; Zhang, Z. Global analysis of the AP2/ERF gene family in rose (Rosa chinensis) genome unveils the role of RcERF099 in Botrytis resistance. BMC Plant Biol. 2020, 20, 1-15. [CrossRef]

96. Mekapogu, M.; Kwon, O.K.; Lee, K.J.; Ahn, M.S.; Park, J.T.; Jung, J.A. Identification of standard type cultivars in Chrysanthemum (Dendranthema grandiflorum) using SSR markers. Hortic. Environ. Biotechnol. 2020, 61, 153-161. [CrossRef]

97. Mekapogu, M.; Vasamsetti, B.M.K.; Kwon, O.-K.; Ahn, M.-S.; Lim, S.-H.; Jung, J.-A. Anthocyanins in Floral Colors: Biosynthesis and Regulation in Chrysanthemum Flowers. Int. J. Mol. Sci. 2020, 21, 6537. [CrossRef] [PubMed]

98. Dowrick, G.; El-Bayoumi, A. The origin of new forms of the garden Chrysanthemum. Euphytica 1966, $15,32-38$.

99. Fukai, S.; de Jong, J.; Rademaker, W. Efficient genetic transformation of chrysanthemum (Dendranthema grandiflorum (Ramat.) Kitamura) using stem segments. Jpn. J. Breed. 1995, 45, 179-184. [CrossRef]

100. Yu, M.; Liu, Z.; Chen, S.; Chen, F. Expression of P. mume PGIP gene in transgenic Dendranthema morifolium increased tolerance to disease resistance. Acta Bot. Boreal. Occident. Sin. 2010, 30, 1111-1116.

101. Xu, G.; Chen, S.; Chen, F. Transgenic chrysanthemum plants expressing a harpin Xoo gene demonstrate induced resistance to Alternaria leaf spot and accelerated development. Russ. J. Plant Physiol. 2010, 57, 548-553. [CrossRef]

102. Sen, S.; Kumar, S.; Ghani, M.; Thakur, M. Agrobacterium mediated genetic transformation of chrysanthemum (Dendranthema grandiflora Tzvelev) with rice chitinase gene for improved resistance against Septoria obesa. Plant Pathol. J. 2013, 12, 1-10. [CrossRef]

103. Takatsu, Y.; Nishizawa, Y.; Hibi, T.; Akutsu, K. Transgenic chrysanthemum (Dendranthema grandiflorum (Ramat.) Kitamura) expressing a rice chitinase gene shows enhanced resistance to gray mold (Botrytis cinerea). Sci. Hortic. 1999, 82, 113-123. [CrossRef]

104. Kim, Y.-S.; Lim, S.; Yoda, H.; Choi, Y.-E.; Sano, H. Simultaneous activation of salicylate production and fungal resistance in transgenic chrysanthemum producing caffeine. Plant Signal. Behav. 2011, 6, 409-412. [CrossRef]

105. Kim, Y.-S.; Choi, Y.-E.; Sano, H. Plant vaccination: Stimulation of defense system by caffeine production in planta. Plant Signal. Behav. 2010, 5, 489-493. [CrossRef]

106. Park, K.S.; Kim, C.H. Effect of temperature and $\mathrm{pH}$ on sporidia formation of Puccinia horiana on chrysanthemum and evaluation of varietal resistance. Plant Pathol. J. 1993, 9, 42-46.

107. Dickens, J. Infection of chrysanthemum flowers by white rust (Puccinia horiana Henn.). Plant Pathol. 1970, 19, 122-124. [CrossRef]

108. Ichikawa, H.; Kato, K.; Mochizuki, A.; Shinoyama, H.; Mitsuhara, I. Transgenic chrysanthemums (Chrysanthemum morifolium Ramat.) carrying both insect and disease resistance. Acta Hortic. 2015, 1087, 485-497.

109. Bi, M.; Li, X.; Yan, X.; Liu, D.; Gao, G.; Zhu, P.; Mao, H. Chrysanthemum WRKY15-1 promotes resistance to Puccinia horiana Henn. via the salicylic acid signaling pathway. Hortic. Res. 2021, 8, 1-11. [CrossRef]

110. Bombarely, A.; Moser, M.; Amrad, A.; Bao, M.; Bapaume, L.; Barry, C.S.; Bliek, M.; Boersma, M.R.; Borghi, L.; Bruggmann, R. Insight into the evolution of the Solanaceae from the parental genomes of Petunia hybrida. Nat. Plants 2016, 2, 1-9. [CrossRef]

111. Vandenbussche, M.; Chambrier, P.; Rodrigues Bento, S.; Morel, P. Petunia, your next supermodel? Front. Plant Sci. 2016, 7, 72. [CrossRef] [PubMed]

112. Kiss, L.; Jankovics, T.; Kovács, G.M.; Daughtrey, M.L. Oidium longipes, a new powdery mildew fungus on petunia in the USA: A potential threat to ornamental and vegetable solanaceous crops. Plant Dis. 2008, 92, 818-825. [CrossRef] [PubMed]

113. Gould, A.B.; Kobayashi, D.Y.; Bergen, M.S. Identification of bacteria for biological control of Botrytis cinerea on petunia using a petal disk assay. Plant Dis. 1996, 80, 1029-1033. [CrossRef] 
114. Esposito, S.; Colucci, M.; Frusciante, L.; Filippone, E.; Lorito, M.; Bressan, R. Antifungal transgenes expression in Petunia hybrida. Acta Hortic. 2000, 508, 157-162. [CrossRef]

115. Khan, R.S.; Alam, S.S.; Munir, I.; Azadi, P.; Nakamura, I.; Mii, M. Botrytis cinerea-resistant marker-free Petunia hybrida produced using the MAT vector system. Plant Cell Tissue Organ Cult. 2011, 106, 11-20. [CrossRef]

116. Khan, R.S.; Kameya, N.; Mii, M.; Nakamura, I. Transgenic Petunia hybrida expressing a synthetic fungal chitinase gene confers disease tolerance to Botrytis cinerea. Plant Biotechnol. 2012, 29, 285-291. [CrossRef]

117. Jiang, P.; Chen, Y.; Wilde, H.D. Reduction of MLO1 expression in petunia increases resistance to powdery mildew. Sci. Hortic. 2016, 201, 225-229. [CrossRef]

118. Hou, P.-F.; Chen, C.-Y. Early stages of infection of lily leaves by Botrytis elliptica and B. cinerea. Plant Pathol. Bull. 2003, 12, 103-108.

119. De Cáceres González, F.F.N.; Davey, M.R.; Sanchez, E.C.; Wilson, Z.A. Conferred resistance to Botrytis cinerea in Lilium by overexpression of the RCH10 chitinase gene. Plant Cell Rep. 2015, 34, 1201-1209. [CrossRef]

120. Gao, X.; Zhang, Q.; Zhao, Y.Q.; Yang, J.; He, H.B.; Jia, G.X. The lre-miR159a-LrGAMYB pathway mediates resistance to grey mould infection in Lilium regale. Mol. Plant Pathol. 2020, 21, 749-760. [CrossRef] [PubMed]

121. Lin, C.H.; Pan, Y.C.; Ye, N.H.; Shih, Y.T.; Liu, F.W.; Chen, C.Y. LsGRP1, a class II glycine-rich protein of Lilium, confers plant resistance via mediating innate immune activation and inducing fungal programmed cell death. Mol. Plant Pathol. 2020, 21, 1149-1166. [CrossRef]

122. Sun, D.; Zhang, X.; Li, S.; Jiang, C.-Z.; Zhang, Y.; Niu, L. LrABCF1, a GCN-type ATP-binding cassette transporter from Lilium regale, is involved in defense responses against viral and fungal pathogens. Planta 2016, 244, 1185-1199. [CrossRef]

123. Han, Q.; Chen, R.; Yang, Y.; Cui, X.; Ge, F.; Chen, C.; Liu, D. A glutathione S-transferase gene from Lilium regale Wilson confers transgenic tobacco resistance to Fusarium oxysporum. Sci. Hortic. 2016, 198, 370-378. [CrossRef]

124. Li, H.; Liu, D.; He, H.; Zhang, N.; Ge, F.; Chen, C. Molecular cloning of a 14-3-3 protein gene from Lilium regale Wilson and overexpression of this gene in tobacco increased resistance to pathogenic fungi. Sci. Hortic. 2014, 168, 9-16. [CrossRef]

125. Rao, J.; Liu, D.; Zhang, N.; He, H.; Ge, F.; Chen, C. Differential gene expression in incompatible interaction between Lilium regale Wilson and Fusarium oxysporum f. sp. lilii revealed by combined SSH and microarray analysis. Mol. Biol. 2014, 48, 802-812. [CrossRef]

126. He, H.; Liu, D.; Zhang, N.; Zheng, W.; Han, Q.; Ji, B.; Ge, F.; Chen, C. The PR10 gene family is highly expressed in Lilium regale Wilson during Fusarium oxysporum f. sp. lilii infection. Gen. Genom. 2014, 36, 497-507. [CrossRef]

127. Zhang, N.; Guan, R.; Yang, Y.; Bai, Z.; Ge, F.; Liu, D. Isolation and characterization of a Fusarium oxysporum-resistant gene LrGLP1 from Lilium regale Wilson. Vitr. Cell. Dev. Biol. Plant 2017, 53, 461-468. [CrossRef]

128. Zuker, A.; Shklarman, E.; Scovel, G.; Ben-Meir, H.; Ovadis, M.; Neta-Sharir, I.; Ben-Yephet, Y.; Weiss, D.; Watad, A.; Vainstein, A. Genetic Engineering of Agronomic and Ornamental Traits in Carnation. Acta Hortic. 2001, 560, 91-94. [CrossRef]

129. Brugliera, F.; Kalc-Wright, G.; Hyland, C.; Webb, L.; Herbert, S.; Sheehan, B.; Mason, J. Improvement of Fusarium wilt tolerance in carnations expressing chitinase. Int. Plant Mol. Biol. Rep. 2000, 18, 522-529.

130. Ahn, B.; Shin, H.; Hwang, K.; Min, B.; Joung, H. Transformation of carnations with jasmonate methyl transferase gene for fusarium tolerance. In Vitro Cell. Dev. Biol. 2004, 40, 45A.

131. Kamo, K.; Lakshman, D.; Bauchan, G.; Rajasekaran, K.; Cary, J.; Jaynes, J. Expression of a synthetic antimicrobial peptide, D4E1, in Gladiolus plants for resistance to Fusarium oxysporum f. sp. gladioli. Plant Cell, Tiss. Org. Cul. 2015, 121, 459-467. [CrossRef]

132. Kamo, K.; Lakshman, D.; Pandey, R.; Guaragna, M.A.; Okubara, P.; Rajasekaran, K.; Cary, J.; Jordan, R. Resistance to Fusarium oxysporum $\mathrm{f}$. sp. gladioli in transgenic Gladiolus plants expressing either a bacterial chloroperoxidase or fungal chitinase genes. Plant Cell Tissuse Organ Cult. 2016, 124, 541-553. [CrossRef]

133. Bi, Y.-M.; Cammue, B.; Goodwin, P.; KrishnaRaj, S.; Saxena, P. Resistance to Botrytis cinerea in scented geranium transformed with a gene encoding the antimicrobial protein Ace-AMP1. Plant Cell Rep. 1999, 18, 835-840. [CrossRef]

134. Narendra Ram, M.; Mohandas, S. Transformation of african violet (Saintpaulia ionantha) with glucanasechitinase genes using Agrobacterium tumefaciens. Acta Hortic. 2003, 624, 471-478. [CrossRef]

135. Wang, Y.; Browning, M.; Ruemmele, B.A.; Chandlee, J.M.; Kausch, A.P.; Jackson, N. Glufosinate reduces fungal diseases in transgenic glufosinate-resistant bentgrasses (Agrostis spp). Weed Sci. 2003, 51, 130-137. [CrossRef]

136. Bhattarai, K.; Conesa, A.; Xiao, S.; Peres, N.A.; Clark, D.G.; Parajuli, S.; Deng, Z. Sequencing and analysis of gerbera daisy leaf transcriptomes reveal disease resistance and susceptibility genes differentially expressed and associated with powdery mildew resistance. BMC Plant Biol. 2020, 20, 1-17. [CrossRef]

137. Nunes, C.C.; Dean, R.A. Host-induced gene silencing: A tool for understanding fungal host interaction and for developing novel disease control strategies. Mol. Plant Pathol. 2012, 13, 519-529. [CrossRef] [PubMed]

138. Koch, A.; Kumar, N.; Weber, L.; Keller, H.; Imani, J.; Kogel, K.-H. Host-induced gene silencing of cytochrome P450 lanosterol C14 $\alpha$ demethylase-encoding genes confers strong resistance to Fusarium species. Proc. Nat. Acad. Sci. USA 2013, 110, 19324-19329. [CrossRef] [PubMed]

139. Wang, M.; Jin, H. Spray-induced gene silencing: A powerful innovative strategy for crop protection. Trends Microbiol. 2017, 25, 4-6. [CrossRef] [PubMed]

140. Sang, H.; Kim, J.-I. Advanced strategies to control plant pathogenic fungi by host-induced gene silencing (HIGS) and sprayinduced gene silencing (SIGS). Plant Biotechnol. Rep. 2020, 14, 1-8. [CrossRef] 
141. Andrade, C.; Tinoco, M.; Rieth, A.; Maia, F.; Aragão, F. Host-induced gene silencing in the necrotrophic fungal pathogen Sclerotinia sclerotiorum. Plant Pathol. 2016, 65, 626-632. [CrossRef]

142. Dou, T.; Shao, X.; Hu, C.; Liu, S.; Sheng, O.; Bi, F.; Deng, G.; Ding, L.; Li, C.; Dong, T. Host-induced gene silencing of Foc TR4 ERG6/11 genes exhibits superior resistance to Fusarium wilt of banana. Plant Biotechnol. J. 2020, 18, 11. [CrossRef] [PubMed]

143. Song, Y.; Thomma, B.P. Host-induced gene silencing compromises Verticillium wilt in tomato and Arabidopsis. Mol. Plant Pathol. 2018, 19, 77-89. [CrossRef]

144. Jahan, S.N.; Åsman, A.K.; Corcoran, P.; Fogelqvist, J.; Vetukuri, R.R.; Dixelius, C. Plant-mediated gene silencing restricts growth of the potato late blight pathogen Phytophthora infestans. J. Exp. Bot. 2015, 66, 2785-2794. [CrossRef] [PubMed]

145. Pliego, C.; Nowara, D.; Bonciani, G.; Gheorghe, D.M.; Xu, R.; Surana, P.; Whigham, E.; Nettleton, D.; Bogdanove, A.J.; Wise, R.P. Host-induced gene silencing in barley powdery mildew reveals a class of ribonuclease-like effectors. Mol. Plant-Microbe Int. 2013, 26, 633-642. [CrossRef]

146. Cheng, W.; Song, X.S.; Li, H.P.; Cao, L.H.; Sun, K.; Qiu, X.L.; Xu, Y.B.; Yang, P.; Huang, T.; Zhang, J.B. Host-induced gene silencing of an essential chitin synthase gene confers durable resistance to $\mathrm{F}$ usarium head blight and seedling blight in wheat. Plant Biotechnol. J. 2015, 13, 1335-1345. [CrossRef]

147. Chen, W.; Kastner, C.; Nowara, D.; Oliveira-Garcia, E.; Rutten, T.; Zhao, Y.; Deising, H.B.; Kumlehn, J.; Schweizer, P. Host-induced silencing of Fusarium culmorum genes protects wheat from infection. J. Exp. Bot. 2016, 67, 4979-4991. [CrossRef]

148. Zhu, L.; Zhu, J.; Liu, Z.; Wang, Z.; Zhou, C.; Wang, H. Host-induced gene silencing of rice blast fungus Magnaporthe oryzae pathogenicity genes mediated by the brome mosaic virus. Genes 2017, 8, 241. [CrossRef]

149. Zhu, X.; Qi, T.; Yang, Q.; He, F.; Tan, C.; Ma, W.; Voegele, R.T.; Kang, Z.; Guo, J. Host-induced gene silencing of the MAPKK gene PsFUZ7 confers stable resistance to wheat stripe rust. Plant Physiol. 2017, 175, 1853-1863. [CrossRef]

150. Qi, T.; Zhu, X.; Tan, C.; Liu, P.; Guo, J.; Kang, Z.; Guo, J. Host-induced gene silencing of an important pathogenicity factor P s CPK 1 in Puccinia striiformis f. sp. tritici enhances resistance of wheat to stripe rust. Plant Biotechnol. J. 2018, 16, 797-807. [CrossRef]

151. Panwar, V.; Jordan, M.; McCallum, B.; Bakkeren, G. Host-induced silencing of essential genes in Puccinia triticina through transgenic expression of RNA i sequences reduces severity of leaf rust infection in wheat. Plant Biotechnol. J. 2018, 16, 1013-1023. [CrossRef]

152. Wang, M.; Weiberg, A.; Lin, F.-M.; Thomma, B.P.; Huang, H.-D.; Jin, H. Bidirectional cross-kingdom RNAi and fungal uptake of external RNAs confer plant protection. Nat. Plants 2016, 2, 1-10. [CrossRef]

153. McLoughlin, A.G.; Wytinck, N.; Walker, P.L.; Girard, I.J.; Rashid, K.Y.; de Kievit, T.; Fernando, W.D.; Whyard, S.; Belmonte, M.F. Identification and application of exogenous dsRNA confers plant protection against Sclerotinia sclerotiorum and Botrytis cinerea. Sci. Rep. 2018, 8, 1-14. [CrossRef]

154. Lau, S.E.; Schwarzacher, T.; Othman, R.Y.; Harikrishna, J.A. dsRNA silencing of an R2R3-MYB transcription factor affects flower cell shape in a Dendrobium hybrid. BMC Plant Biol. 2015, 15, 1-14. [CrossRef] [PubMed]

155. Davalos, A.; Henriques, R.; Latasa, M.J.; Laparra, M.; Coca, M. Literature review of baseline information on non-coding RNA (ncRNA) to support the risk assessment of ncRNA-based genetically modified plants for food and feed. EFSA Supp. Publ. 2019, 16, 220. [CrossRef]

156. Fletcher, S.J.; Reeves, P.T.; Hong, B.T.; Mitter, N. A perspective on RNAi-based biopesticides. Front. Plant Sci. $2020,11,51$. [CrossRef]

157. Casacuberta, J.M.; Devos, Y.; du Jardin, P.; Ramon, M.; Vaucheret, H.; Nogue, F. Biotechnological uses of RNAi in plants: Risk assessment considerations. Trends Biotechnol. 2015, 33, 145-147. [CrossRef]

158. Papadopoulou, N.; Devos, Y.; Alvarez-Alfageme, F.; Lanzoni, A.; Waigmann, E. Risk assessment considerations for genetically modified RNAi plants: EFSA's activities and perspective. Front. Plant Sci. 2020, 11, 445. [CrossRef] [PubMed]

159. Naito, Y.; Yamada, T.; Matsumiya, T.; Ui-Tei, K.; Saigo, K.; Morishita, S. dsCheck: Highly sensitive off-target search software for double-stranded RNA-mediated RNA interference. Nucleic Acids Res. 2005, 33, 589-591. [CrossRef] [PubMed] 